\title{
Diversity in Academic Biomedicine: An Evaluation of Education and Career Outcomes with Implications for Policy
}

\author{
Donna K. Ginther \\ Professor, Department of Economics, University of Kansas \\ Lawrence, KS 66045 \\ Walter T. Schaffer \\ Senior Scientific Advisor for Extramural Research, National Institutes of Health \\ Bethesda, Maryland 20892 \\ Joshua Schnell \\ Director, Analytics, Discovery Logic, Rockville, MD 20895 \\ Beth Masimore \\ Analyst, Discovery Logic, Rockville, MD 20895 \\ Faye Liu \\ Analyst, Discovery Logic, Rockville, MD 20895 \\ Laurel L. Haak \\ Chief Science Officer, Discovery Logic, Rockville, MD 20895 \\ Raynard S. Kington \\ Deputy Director, National Institutes of Health \\ Bethesda, Maryland 20892
}

September 22, 2009

\begin{abstract}
Acknowledgements: Ginther acknowledges financial support from NSF grants SES-0353703 and SBE0738347 and thanks Serena Huang and Hajar Aghababa for research assistance. Discovery Logic acknowledges support from NIH contracts HHSN276200800458U and HHSN276200900100U made possible through an NIH Evaluation Set aside Award (07-6008 OD OER). The use of NSF data does not imply NSF endorsement of the research, research methods, or conclusions contained in this report. Any errors are our own responsibility. Corresponding author: Donna K. Ginther, Economics Department, 333 Snow Hall, 1460 Jayhawk Blvd, Lawrence, KS 66045-7585; Phone: (785)864-3251; Fax: (785)8645270; Email: dginther@ku.edu.
\end{abstract}




\begin{abstract}
Currently, the U.S. population is undergoing major racial and ethnic demographic shifts that could affect the pool of individuals interested in pursuing a career in biomedical research. To achieve its mission of improving health, the National Institutes of Health must recruit and train outstanding individuals for the biomedical workforce. In this study, we examined the educational transition rates in the biomedical sciences by gender, race, and ethnicity, from high school to academic career outcomes. Using a number of educational databases, we investigated gender and racial/ethnic representation at typical educational and career milestones en route to faculty careers in biomedicine. We then employed multivariate regression methods to examine faculty career outcomes, using the National Science Foundation's Survey of Doctorate Recipients. We find that while transitions between milestones are distinctive by gender and race/ethnicity, the transitions between high school and college and between college and graduate school are critical points at which underrepresented minorities are lost from the biomedical pipeline, suggesting some specific targets for policy intervention.
\end{abstract}

JEL Codes: J4, J71. Key words: Scientific labor force, race, gender, diversity, career outcomes, science policy. 


\section{INTRODUCTION}

Estimates suggest that while the overall number of high school graduates in the U.S. will not surpass the current peak of 3.4 million within the next 15 years, the proportion of students from underrepresented minority groups will increase dramatically (Western Interstate Commission for Higher Education, 2008). Of concern is the evidence that these students are less likely to pursue higher education and in particular, careers in biomedical science (Lee, 1991; Ntiri, 2001; Opp, 2001; Thomas and Thurber, 1999). In 1997, underrepresented minorities accounted for a mere 4.2 percent of the doctoral-level biomedical workforce (Lopatto, 2004; NAS, 2005). As of 2005, the overall representation of minorities in biomedical research was 5.3 percent, despite an average annual increase of 15 percent in the U.S. minority population over the past decade (NRC, 2005). An analysis by Nelson (2007) found that there were very few underrepresented minorities on the faculties of Research I institutions, although the report did not identify the causes behind these small numbers.

The National Institutes of Health $(\mathrm{NIH})$ and others have stated the importance of diversity in the health and biomedical workforce for health outcomes and biomedical research. The Sullivan Report argues that without increased racial and ethnic diversity in the health professions, the nation may be putting the health of minority populations at risk (Sullivan Commission, 2004). The NIH provides research supplements to promote diversity in health research in order to enhance the quality of education, to increase the recruitment and participation of minority groups in clinical trials, lead to improved patient satisfaction in order to enhance clinical research, and to increase research in areas related to health disparities and minority health $(\mathrm{NIH}, 2008)$. The NIH proposal announcement to promote diversity concludes: "There is no question that the need for a diverse workforce permeates all aspects of the nation's health-related research effort" $(\mathrm{NIH}, 2008)$. The goal of this study is to understand the factors that contribute to diversity (or lack thereof) in the academic biomedical workforce and thereby identify leverage points for policy actions.

The majority of the research on educational and career transition experiences in science has focused on women. A National Academies report indicated two major transition points at 
which women leave science and engineering career paths: first, the transition from high school to college, and then from graduate school to tenure-track faculty positions (NAS, 2007). Although more women than men indicate an expectation to attend and complete college, men are 60 percent more likely to pursue a science or engineering major (Xie and Shauman, 2003). Once in graduate school, women and men have similar rates of degree completion; however women are less likely to make the transition from completion of doctoral degree to faculty appointment, possibly attributable to a lack of mentorship from graduate advisors (Nettles and Millett, 2006) or prestige of the academic institution (Gaughan and Robin, 2006), particularly for minority women (Leggon and Pearson, 1997).

Research on underrepresented minorities in science is much less prevalent. As with women, the NSF reports biennially on the numbers of underrepresented minorities in science occupations (NSF, 2009). Like the Nelson report, the NSF study documents the small number of minorities in faculty positions without fully investigating the underlying causes of their underrepresentation. A National Academies workshop on factors affecting the numbers of minority scientists pursuing research careers (Olson and Fagen 2007)identified three outstanding research questions:

1. What are the probabilities that an individual with a given set of characteristics will make the transition from one career stage to another?

2. What factors influence career-stage transition decisions, and are these decisions predicted by demographic characteristics?

3. How can these probabilities be changed?

Clearly, progress cannot be made in addressing questions (2) and (3) without first examining factors associated with transitions from one career stage to the next. Our study will address research question (1) at all stages of the career path .

A select few studies go beyond the numbers in providing explanations for minority underrepresentation in science careers. Brown (2000) provides an analysis similar to this study, documenting the pipeline for all minority scientists through the early 1990s. She attributes much of the under-representation of minorities in academic science to attrition from science and engineering majors, but does not examine whether minority scientists are treated 
differently on the tenure track than their majority colleagues. Turner, Myers and Creswell (1999) interviewed faculty of color in Midwestern universities, and they attribute low numbers of minorities in academic science to low numbers in the pipeline and a chilly climate in academia. Like Brown, their study only goes through the 1990s. Jackson (2004) echoes these findings. Her survey shows that women and minorities in STEM fields feel less support and perceive the tenure process to be less fair than white male respondents. These qualitative studies do not directly address whether hiring and the tenure process contributes to the underrepresentation of minorities in academic science. We seek to address this shortcoming in our analysis.

Several studies have indicated that many students, particularly women and minorities, who enter college with the intent of pursuing a degree in science abandon that goal (NAS, 2007). In many cases, this decision is made not because of a lack of preparation or individual capability, but because of the environment of science departments (Seymour and Hewitt, 1997; Grandy, 1998; Brown, 2000). Undergraduate research programs may play a significant positive role in the decision to pursue doctoral studies in the biomedical sciences (Villarejo et al., 2008), but there is evidence to indicate that graduate research fellowships may deter students from continuing in academic science and engineering careers (Nettles and Millett, 2006; Gaughan and Robins, 2004).

It is clear that health outcomes and treatment protocols may differ for men and women as well as by race/ethnicity. To promote research into minority health and health disparities, Congress established the NIH Office of Research on Minority Health in $1990 .^{1}$ To the extent that researchers of diverse racial and ethnic backgrounds are more likely to investigate the problems associated with their demographic group, racial and ethnic diversity in biomedical science should give rise to improved treatment outcomes (Leggon and Malcom 1994, Leggon 2006). In addition, Schiebinger (2008) and others (see, e.g., Cox, 1993; McLeod et al., 1996; Thomas, 2004) argue that diversity in the workforce has the overall effect of enhancing innovation.

\footnotetext{
${ }^{1}$ The NIH Revitalization Act of 1993 added a requirement that NIH include women and minorities as subjects in clinical research. In 2000, the ORMH became the National Center on Minority Health and Health Disparities, established by the passage of the Minority Health and Health Disparities Research and Education Act of 2000. Public Law 106-525.
} 
In this study we seek to better understand why minority representation in the academic biomedical workforce lags behind that of the general population. In particular, does lack of diversity in academic biomedicine arise because of differences in education and training? Or is it the end-result of differences in hiring and promotion? To address the first question, we determined transition rates by gender, race, and ethnicity between specific education and career stages for seven hypothetical high school graduating cohorts from 1981-1996 by integrating and linking extant data for high school completion; college, graduate, and medical student matriculation and completion; and presence on faculty at American Medical Colleges in the United States. In the second part of the study, we examined gender and racial differences in the academic biomedical career outcomes of obtaining a tenure track job, getting promoted to tenure, and receiving NIH and NSF funding using the National Science Foundation's Survey of Doctorate Recipients (SDR).

Our results indicate that women and minorities have increased their participation in biological science majors, however women and minorities face different difficulties on the academic biomedical career path. Women are increasingly completing graduate and medical school, but are less likely to secure tenure track jobs. The loss of all racial minorities except Asians occurs in both college completion and graduate school completion, where low graduation rates underlie low representation all along the academic pathway. Once on the tenure track, we find few demographic differences in the probability of receiving tenure or obtaining research funding from the NIH or NSF. This suggests that the lack of racial/ethnic diversity in academic biomedicine occurs much earlier in the education pipeline-in high school, college and graduate school, as opposed to later in the academic career.

This study is organized as follows: Section 2 describes the data and methods, Section 3 presents the findings of transition ratios between educational and career milestones, Section 4 presents the findings of the model of faculty outcomes for PhD recipients between 1985 and 1996, and Section 5 discusses the findings in the context of NIH policy. 


\section{METHODS}

\subsection{Education and Career Transitions: Establishing Milestones}

We analyzed proportional representation of demographic groups at specific educational and career milestones. We separately considered gender and race/ethnicity at milestones in the educational and training path for a typical member of the U.S. biomedical workforce, as allowed by the availability of data. We used a linear model of a biomedical academic career pathway with the milestones shown in Figure 1. Between 15 and 30 percent of the biomedical workforce seeking NIH funding have received either a Medical Doctorate or combined Medical and Academic Doctorate degrees. The remainder hold Academic Doctorates in biomedical science. Because of differences in matriculation and completion between medical school students and graduate students, we have conducted the analysis for both PhDs and MDs. Data sources and assumptions on the lag between milestones are specified in Table 1.

\subsection{Determination of Aggregate Demographic Trends: Data Sources}

Because of differences in data collection between sources and across time, we considered the following racial and ethnic groups for this study: African American/Black, American Indian (includes Alaska Natives), Asian/Pacific Islander, Hispanic (includes Mexican American and Puerto Rican), and White. Races and ethnicities were self-identified and in many cases were reported only for U.S. citizens and permanent residents. The available data leave the following gaps:

- Inconsistent data on gender and race/ethnicity of all (public, private, and homeschooled) high school completers.

- Sporadic data collection on progression through college and demographic-specific completion rates.

- Limited and poor quality data for postdoctoral researchers, including a complete lack of race/ethnicity data. 
- Limited and inconsistent data for faculty at academic institutions, including country of origin and tenure status.

Even with these limitations, it was possible to aggregate the existing data sources to examine the demographics of educational and career transitions. Specific data issues are described for each data source:

High School Completion: The National Center for Education Statistics (NCES) is the primary federal entity for collecting and analyzing data related to education. The NCESadministered State Nonfiscal Public Elementary / Secondary School Survey provides the most relevant data pertaining to the number of high school completers (Sable and Garofano, 2007). ${ }^{2}$ The NCES-administered Common Core of Data provides additional statistics, including the Average Freshman Graduate Rate (AFGR), an estimate of the percentage of the entering high school freshman class graduating in four years.

Completion of Bachelor Degree: The Integrated Postsecondary Education Data System (IPEDS) Completions Survey is conducted by the National Center for Education Statistics and provided by the National Science Foundation (NSF) via their online WebCASPAR data service. IPEDS provides gender and race/ethnicity data for Bachelor's degree recipients from providers of postsecondary education. ${ }^{3}$ Prior to 1989 , race and ethnicity data were only collected in select years. The IPEDS survey relies on educational institutions to collect and report student demographic information. Schools are required to classify students in one of the following categories: White, Black, Hispanic, Asian or Pacific Islander, American Indian or Alaska Native, Temporary, or Unknown. Students could not be classified in more than one category. Students who were not

\footnotetext{
${ }^{2}$ This annual survey of state education departments collects basic information on public elementary and secondary students and staff, including number of public high school graduates. The survey began collecting race/ethnicity data in 1992, and states were required to classify students as one of the following: White, Black, Hispanic, Asian or Pacific Islander, American Indian or Alaska Native..

${ }^{3}$ Included in the IPEDS survey are institutions that are open to the general public and offering formal programs designed primarily for students beyond the compulsory high school age. All of the data presented in this report are for the NSF population of institutions (as opposed to the NCES population). The NSF Department of Science Resources Statistics regards the coverage of this survey to be 'very high'. The list of surveyed institutions is updated yearly. IPEDS Completions Survey, National Science Foundation, Arlington, VA, http://www.nsf.gov/statistics/showsrvy.cfm?srvy CatID=2\&srvy Seri=4; IPEDS, National Center for Educational Statistics, Institute of Education Sciences, U.S. Department of Education, Washington, DC, http://nces.ed.gov/ipeds/.
} 
citizens or permanent residents are classified as Temporary, regardless of race. The 1997 OMB directive regarding race/ethnicity classification was implemented for the first time in the fall 2008 IPEDS survey. ${ }^{4}$

Completion of Academic Doctoral Degree: NSF began the Survey of Earned Doctorates (SED) in 1957-58 to continuously collect data on the number and characteristics of individuals receiving research doctoral degrees from all accredited U.S. institutions. All individuals are asked to complete the survey as part of their degree completion and U.S. institutions are responsible for providing and submitting the surveys. The study has over a 90 percent response rate and limited records are constructed for non-respondents based on university public records.

\section{Completion of Physician Doctoral Degree: The American Association of Medical}

Colleges (AAMC) administers the Student Records System to collect information on the national medical student population and to track student progress from matriculation through graduation. ${ }^{5}$

Transition from Doctoral Degree to Tenure-Track Faculty Position: We obtained data on faculty position from two data sources. The AAMC conducts an annual survey of its 129 member institutions $^{6}$ that gathers data on the gender and race/ethnicity of faculty at these institutions in both basic science and clinical science departments. In 2006, approximately two-thirds of R01 funding across the NIH was granted to medical schools,

\footnotetext{
${ }^{4}$ Morgan, F (2008) Postsecondary Studies Division, National Center for Education Statistics, personal communications.

${ }^{5}$ These data are compiled in the AAMC Data Warehouse Student File (DW:S) and published annually in the AAMC Data Book. Additional information is collected through the Liaison Committee on Medical Education (LCME) Part II Survey. Data prior to 1978 were derived from the LCME survey and post 1978 data derive from the DW:S. Race and ethnicity are self-identified; percent of total may not sum to 100 percent as individuals may select multiple categories. Prior to the 2000 Census, Native Hawaiians were categorized under'Asian or Pacific Islander'; after2000, the category was separated into two: Asian and Native Hawaiian or Other Pacific Islander, and 'Native American' was redefined to include American Indian orAlaska Native. See, Revisions to the Standards for the Classification of Federal Data on Race and Ethnicity (OMB Directive 15) To facilitate comparisons among other data sets in this report, 'Mexican American', 'Puerto Rican (Commonwealth), 'Puerto Rican (Mainland)", and 'Other Hispanic' were combined into a single category, 'Hispanic.' Races and ethnicities were reported only for U.S. citizens and permanent residents. AAMC Data Book: Medical Schools and Teaching Hospitals by the Numbers 2007, Table 8, Association of American Medical Colleges, Washington, DC; FACTS - Applications, Matriculants, Graduates, and Residency Applicants, Association of American Medical Colleges, Washington, DC, http://www.aamc.org/data/facts/2007/2007slr2.htm.

${ }^{6}$ Accredited U.S. Medical Schools. Member list available at http://services.aamc.org/memberlistings/index.cfm?fuseaction= home.search\&search_type=MS\&wildcard_criteria=\&state_criteria=CNT\%3AUSA\&image=Search.
} 
therefore these data are likely to be indicative of the whole pool of R01 applicants. ${ }^{7}$

Through the Survey of Doctoral Recipients (SDR), NSF gathers employment information from individuals who have obtained a PhD in a science, engineering or health field. The SDR is a biennial, longitudinal survey of about 10 percent of the recipients of academic doctorates from U.S. institutions, from matriculation until age 76. The SDR collects detailed information on demographic characteristics, educational background, employer characteristics, academic rank, government support, primary work activity, productivity, and salary. From the 1973 through 1991 surveys, respondents provided the exact year that they received tenure, but for later surveys, tenure year is imputed as the first year a person is observed with tenure in the sample. Given the biennial nature of the survey, years until tenure may be measured with one-year error.

\subsection{Analysis of Transitions between Education and Career Milestones}

After collecting aggregate date for each milestone, we grouped data into cohort pools of defined time periods for each milestone and determined if the proportional representation of group members in each cohort changed significantly from one milestone to the next. Only U.S. Citizens and permanent residents were included in this analysis. Categorical chi-square tests were used to test for differences in proportional representation per demographic group at each education and career milestone. These analyses were extended across years to illustrate the demographic trends from one milestone to the next.

\subsection{Determination of Individual-Level Career Outcomes Using the Survey of Doctorate Recipients}

After documenting trends in the aggregate data, we investigated gender and racial/ethnic differences in academic career outcomes using the 1985- 2006 waves of the Survey of Doctorate Recipients (SDR). We selected a longitudinal extract of academic doctorate

\footnotetext{
${ }^{7}$ This percentage was calculated using the "Aggregate Data 2006" data file from the NIH Research Portfolio Online Reporting Tool (RePORT) accessed at http://report.nih.gov/award/trends/AggregateData.cfm?Year=2006 on July 29, 2006. Of the 29,413 projects beginning with 'R01', 9,226 $(\$ 3,259,303,976)$ contained a value of ' $N o^{\prime}$ in the Medical-School Flag column, and 20,187 $(\$ 6,879,789,406)$ contained a value of 'Yes' in the Medical-School Flag column.
} 
recipients in the biomedical sciences who received their PhD between the years of 1985 and 1996 and remain in the survey 10 years after the PhD. Individuals are excluded if they are not observed more than once or if they skip more than three surveys.

We estimated three career milestones. First, using probit analysis we examined the probability of obtaining a tenure track job within seven years of the PhD. We then restricted the probit analysis to those who have ever held a tenure track job to estimate the probability of the first award of tenure within 10 years of the PhD. Finally, we estimate the probability that an individual received NIH or NSF funding within 10 years of the PhD.

Our analyses include both time-varying and non-time varying independent variables. Non-time varying variables include gender, race, whether foreign born, degree field, and aspects of the person's PhD institution. Time-varying independent variables include marital status, children, current and past employer characteristics, primary and secondary work activities, government support, and limited productivity measures (discussed below). These covariates are suggested by previous studies of academic promotion (Ginther and Hayes, 2003; Ginther and Kahn, 2004). Appendix Table 1 includes variable definitions and descriptive statistics for the tenure track and tenure and funding samples.

Measures of academic productivity are largely missing from the SDR data, but the SDR does ask questions about publications in the 1983, 1995, 2001, and 2003 surveys. The 1983 question refers to publications between 1980 and 1983 whereas the 1995, 2001 and 2003 questions refer to numbers of publications in the previous five years. We use these data to create rough measures of cumulative papers presented and publications per year past PhD. If productivity data are missing for a particular year, average observed productivity is used to impute total productivity - an admittedly rough correction which nevertheless seems preferable to omitting the information altogether.

\section{TRANSITION RATIOS BETWEEN EDUCATIONAL AND CAREER MILESTONES}

\subsection{Academic Doctorate Track}


Table 2 shows the number and percent representation of each of the major gender and racial/ethnic groups of seven different cohorts at four career milestones: high school, college completion, graduate school completion and appointment as an assistant professor at a U.S. medical school. Cohort 1, shown in the left-most data column, includes those who finished high school in 1981, completed college in biological sciences in 1985 (four years later), completed graduate school in biological sciences in 1990 (five years later), and were appointed as an assistant professor at a medical school in 1995 (five years later). To compare the trends in numbers and group proportion over time, six more sample cohorts are presented with the years indicated. Race/ethnicity data for high school completers are first available for Cohort 5. Members of Cohorts 6 and 7 are not yet part of the pool of assistant professors at medical schools, and therefore no data are available for these cohorts at this milestone.

The data presented in Table 2 were used to generate a transition ratio. This ratio, shown in Table 3, indicates the persistence of proportional representation of different gender and racial/ethnic groups through the high school to college graduation transition (with a degree in biomedicine), the college graduation to academic doctoral receipt transition, and the transition from doctoral recipient to AAMC Medical School assistant professor. No change between milestones is indicated by a ratio of 1 ; an increase compared to the previous milestone will show a ratio greater than 1; and a ratio less than 1 indicates a proportional loss from one milestone to the next. Proportional change does not necessarily indicate a numerical change in group size. Transition ratios significantly different than $1(p<.05)$ are indicated in bold lettering.

\subsubsection{Transition 1: High school completion to receipt of biological sciences Bachelor's degree}

In considering the differences in transition of males and females for all cohorts, males have experienced a decrease in percent representation from Cohort 3 on, despite increasing numbers of male high school completers and biological bachelor's degree recipients for all cohorts except Cohort 7. For those cohorts for which high school race/ethnicity data are available (Cohorts 5-7), Asian students show a substantial proportional increase between high 
school and college completion; proportional representation falls for Black, American Indian, and Hispanic students; and proportional representation of White students stays relatively constant. These ratios persist across cohorts.

\subsubsection{Transition 2: Receipt of biological sciences Bachelor's degree to receipt of $\underline{\text { biological sciences PhD }}$}

For all cohorts considered, men are overrepresented compared to women among PhD recipients. For recent cohorts (Cohorts 6 and 7), this effect is largely due to the fact that many more women than men receive biological sciences bachelor's degrees, despite the gender ratio of college degree holders being closer to 1 . The proportion of White students transitioning to $\mathrm{PhD}$ completion is close to 1 , and more recently Asians students have been transitioning in decreasing proportion with recent years approaching 1. Once again, the proportion of Black, Hispanic and American Indian students decreases significantly from college completion to graduate school completion, exacerbating the gap between these racial/ethnic groups and Whites and Asians. The large fluctuations in representation of members of the Unknowns category at this transition are likely due to differences in data collection between sources used for Bachelor's degrees and PhD degrees. Interestingly the male-to-female ratio of both Black and Hispanic biological sciences bachelor's degree recipients began favoring women more than a decade earlier than for White degree recipients. ${ }^{8}$ In addition, the transition to doctoral completion for women in these groups has been more similar to men of their group, in contrast to White women.

\subsubsection{Transition 3: Receipt of biological sciences PhD to appointment as assistant} professor

The transition ratios presented in Table 3 for the last transition indicate that women are consistently underrepresented among junior faculty. For the four cohorts for which data at the faculty level are available, men are overrepresented among assistant professors by greater than 10 percent compared to the previous milestone of graduate school completion. The overall

\footnotetext{
${ }^{8}$ These results are available upon request.
} 
numbers of both men and women faculty are increasing and the proportion of women faculty is slowly increasing, but the concomitant increase in the proportion of women completing graduate school suggests that more could be done to bring women to parity with men as new faculty. Chi squared analysis suggests that the male-to-female ratio of postdoctoral researchers is nearly representative of the previous milestone, suggesting that the loss occurs at the transition from postdoctoral research to faculty appointment (data not shown).

The transition ratios for racial and ethnic groups are difficult to interpret due to the unknown racial/ethnic group of a large number of faculty. In our sample, the proportion of Asian and Black professors increase relative to those receiving academic doctorates, while the proportions of Whites, Native Americans, and Hispanics are not significantly different. A study by Myers and Turner (2004) found that female faculty are less represented than male faculty among Blacks, American Indians, and Asian/Pacific Islanders, and that foreign-born faculty are more highly represented than U.S.-born faculty among whites and blacks.

\subsection{Medical Degree Track}

Table 4 presents data for the high school cohorts in Table 2 for medical degree recipients: completion of a biological sciences Bachelor's degree, completion of a medical school degree, and attainment of tenure-track position. Medical School enrollments were stable during the analysis period. Transition ratios for individuals moving through a career track involving a medical degree were calculated using the data from Table 4 and are presented in Table 5.

\subsubsection{Transition 4: Biological sciences bachelor's degree completion to receipt of MD}

The proportion of women completing medical school has been steadily increasing since the 1970s and is close to reaching parity. Since 1979, when race/ethnicity data were first collected for this milestone, the overall number of MD recipients has remained constant, while the number of Black and Hispanic MD recipients increased, thus increasing the proportional representation of these groups. The proportion of Asian MD recipients increased significantly while the number of degrees awarded to American Indians remains small. The number and proportion of White MD degree recipients has dropped steadily since 1983. Similar to doctorate recipients, women are a much higher proportion of Black medical degree recipients 
than men (data not shown). More Native American women complete medical school than men, in contrast to White women. In recent years, Asian women have reached parity with Asian men in completing medical school. ${ }^{9}$ In contrast to the findings of the graduate school track, there is increased representation of minority groups in medical school.

\subsubsection{Transition 5: Medical Degree Receipt to Appointment as Assistant Professor}

The transition data reflect that the tenure-track is not the primary career destination for most medical degree recipients. For all groups except Whites, the transition ratio is less than 1. Compared to graduate school, the transition ratio between medical school and faculty is lower for all groups. There is still a disparity between men and women, but it is smaller as due to a smaller transition ratio for men. The transition ratio for Blacks to medical school faculty, in particular, is much lower for MDs than PhDs.

\section{FACULTY HIRING, PROMOTION, AND GRANT OUTCOMES FOR PHD RECEIPIENTS BETWEEN 1985 AND 2006}

The data presented in Part 1 are aggregated data and are meant to model a cohort of individuals who may move through the typical stages of a biomedical career. Other career pathways exist that involve different terminal degrees than biological sciences, more time between milestones, or different milestones entirely. To address this, we used individual-level data from the NSF Survey of Doctoral Recipients (SDR) to develop probit models of tenure-track attainment, tenure and federal research funding from the NIH and NSF. While the SDR is limited to U.S. PhD recipients, almost 4 out of 5 of the applications received by the NIH for R01 (and equivalent) grants from New Investigators come from PhD holders ${ }^{10}$, most of whom received their $\mathrm{PhD}$ in the U.S. In addition to the categories considered above, we examine whether there are differences in career outcomes as the result of nativity. We do this because

\footnotetext{
${ }^{9}$ Data from AAMC Facts website, http://www.aamc.org/data/facts/2008/gradraceeth0208.htm, accessed on $6 / 8 / 2009$.

${ }^{10}$ This percentage was based on available data for 2004 from the NIH Research Portfolio Online Reporting Tool (RePORT) accessed at http://grants.nih.gov/grants/new_investigators/Average_age_initial_R01.xls, 2009.
} 
close to 30 percent of biological sciences doctorates awarded in the U.S. are awarded to the foreign-born (National Science Foundation, 2007).

\subsection{Tenure Track Job}

Model 1 in Table 6 shows the demographic differences in the probability of receiving a tenure track job within seven years of the doctorate using the $1985-2006$ waves of the SDR. ${ }^{11}$ Our first model indicates that women and blacks are somewhat more likely to get a tenure track job, but this difference is marginally significant $(p<.10)$. Hispanics are 12 percent more likely than whites to have a tenure track job $(p<.01)$. In contrast, Asians and the foreign born are significantly less likely to get hired onto the tenure track. In Model 2, after adding the additional controls of PhD field, the effect of foreign-born increases in statistical significance, and women are no different from men. In Model 3, the addition of PhD Institution characteristics does not change the results substantially, and then controls for PhD Institution characteristics, marital status, and children are included in Model 4, Hispanics remain 12 percent more likely than Whites to get a tenure track job $(p<.01)$, whereas Asians are 7 percent less likely $(p<.05)$. Model 5 includes interaction terms between Foreign-born and race and ethnicity. The Foreign-born coefficient is no longer statistically significant, because it is explained by Foreign-born Blacks' 16 percent disadvantage in getting a tenure track position compared to native-born Whites. ${ }^{12}$ In addition, native-born Blacks are 9 percent more likely to get a tenure track job than whites, and native-born Asians are 8 percent less likely $(p<.10)$ to get a tenure track position.

Overall the results indicate no disadvantage for women. Although Nelson documents very small numbers of underrepresented minorities in Research I institutions, our analysis differs somewhat because we focus on all four-year academic institutions. Our results indicate that native-born Blacks and Hispanics are significantly more likely to get tenure track jobs than whites. Thus, the underrepresentation of these groups in academic careers happens much earlier in the academic pipeline. In contrast, Asians and Foreign-born Blacks are disadvantaged. The difficulty encountered by foreign-born Asian doctorates due to the language-barrier is one

\footnotetext{
${ }^{11}$ Full specifications of these models appear in the appendix.

${ }^{12}$ The total effect of being a foreign-born black is found by adding the coefficients for black, foreign-born and foreign-born*black.
} 
possible explanation for their disadvantage. Although the point estimate is not statistically significant, foreign-born Asians are more likely to get tenure track jobs, although the total effect (Asian + Foreign-Born* Asian) is still negative and marginally significant (-6\%, $p<.10)$.

\subsection{Tenure within 10 Years of PhD}

Although Blacks and Hispanics are more likely than Whites to get tenure track positions, it could be that they are less likely to receive tenure. Table 7 examines the probability of getting tenure within 10 years of the PhD as a function of demographic characteristics. ${ }^{13}{ }^{14}$ Model 1 shows that women are 9 percent less likely to get tenure after controlling for race, age, year of PhD, PhD Field, and the Carnegie ranking of the PhD institution. No other demographic characteristics are statistically significant. As more controls (including publications and government support) are progressively added to Models 3 - 4, women are no longer significantly different from men in getting tenure. When controlling for all variables in Model 4, foreign-born doctorates are 22 percent less likely to get tenure $(p<.01)$. In Model 5 after we include the foreign-born interaction terms, Foreign-born Blacks are 30 percent less likely to get tenure $(p<.11)$. In contrast, native-born Blacks are 22 percent more likely $(p<.05)$ to be tenured than Whites. Thus, the underrepresentation of women, Native-born Blacks, Hispanics, Asians, and Native Americans cannot be explained by demographic differences in the probability of being promoted after the model fully controls for PhD characteristics, marital status, children, employer characteristics, government support and publications. Even without these controls, women were the only group significantly less likely to be promoted. This gender difference is no longer statistically significant after controlling for the number of employers and the current employer's characteristics.

In contrast, Foreign-born scientists are significantly less likely to receive tenure. In a separate analysis, we estimated the probability of getting tenure within 10 years of PhD for Foreign-born scientists only. ${ }^{15}$ Much of the Foreign-born disadvantage can be explained by the

\footnotetext{
${ }^{13}$ Full specification of these models appear in the appendix.

${ }^{14}$ Probit models may be biased by censoring. We have estimated Cox proportional hazard models of the probability of receiving tenure, and these estimates are available upon request. The Cox models show that no gender or demographic characteristics have a statistically significant effect on the hazard of receiving tenure.

${ }^{15}$ These estimates are available upon request.
} 
negative impact of having multiple employers within 10 years of the $\mathrm{PhD}$, being employed at a Medical School, having a PhD field in biochemistry, and being married.

In Table 8 we examine the distribution of where individuals are getting tenure by race/ethnicity, gender, and nativity. We divide four-year universities into categories based on their 2005 Carnegie Classifications: Liberal Arts, Universities, ${ }^{16}$ Research I, and Other (which includes Medical Schools). Tenured faculty are divided into thirds, with one-third being tenured at Liberal Arts institutions, one-third at Research I institutions, and one-third in the remaining categories. Blacks and Native-born individuals have higher tenure rates than the full sample. However, Blacks, Native Americans, Hispanics, and Women are more likely to be tenured at Liberal Arts institutions than any other category. In contrast Asians, the Foreign-born, and men are more likely to be tenured at Research I institutions. Although there are few significant differences in the probability of getting tenure across demographic groups, Table 8 indicates that Blacks, Native Americans, Hispanics, and women are more likely to receive tenure at institutions that specialize in teaching as opposed to research.

\subsection{Federal Research Support}

In addition to receiving tenure, another important career milestone is whether the biomedical scientist receives research funding support from the NIH and NSF. The SDR includes measures of whether the scientist receives NIH or NSF support in the $1985-2003$ waves (the question was omitted from the 2006 survey). Tables 9 and 10 show estimates of the probability that an academic scientist receives NIH and NSF funding after the postdoctorate and within 10 years of the doctorate using the same specifications as in Table $7 .{ }^{17}$ Model 1 in Table 9 indicates that women are 6 percent more likely to get NIH funding $(p<.10)$ than men, whereas Blacks are 13 percent less likely. However, the Black coefficient is no longer statistically significant after adding the full set of controls. Women have an even greater advantage in Model 4, being 8 percent more likely than men $(p<.05)$ to receive NIH funding. This result is at odds with a

\footnotetext{
${ }^{16}$ These are four-year institutions that are not Liberal Arts, Research I, or other types of professional schools such as Medical Schools.

${ }^{17}$ Full specification of these models appear in the appendix.
} 
recent report that shows women are disadvantaged in receiving NIH funding (Hosek 2005). ${ }^{18}$ This discrepancy may be explained by the different time periods used in the analysis as well as different data sources. Adding the Foreign-born interaction terms in Model 5 shows that native-born Asians are 24 percent more likely to receive NIH funding, but the result is only marginally significant $(p<.10)$.

Table 10 shows that Native Americans are 17 percent more likely to receive NSF funding than whites $(p<.10)$. The only group significantly less likely to be funded by NSF are foreignborn Asians. There are no other statistically significant demographic differences in NSF funding.

\section{CONCLUSION AND POLICY IMPLICATIONS}

Our study examined the probabilities that women and under-represented minorities progress along the biomedical academic career track. We have shown that calculating the percent proportion of members of gender and racial/ethnic groups at specific milestones is a useful methodology to illuminate transitions where representation of a specific group significantly increases or decreases. Analyses of trends at each milestone in the career path of a biomedical scientist suggest that women and minorities are increasingly participating in biological sciences education and research careers. However, a closer look at the data shows that members of gender or racial/ethnic groups are not transitioning between milestones in the same proportion.

Significant losses of members of the Black, Hispanic, and Native American groups are observed at the transition from high school completion to college completion in biological sciences. Losses are seen once again for Blacks, Hispanics, and Native Americans as college completers from these racial/ethnic groups who choose the academic track transition to graduate school completion. Interestingly this is in contrast to the situation seen on the medical school track, where the proportional representation of Black, Hispanic, and Native American Medical degree recipients increases when compared to college completers. When

\footnotetext{
${ }^{18}$ We must note that our study and Hosek 2005 cover different years and Hosek 2005 uses NIH grant data for their analysis.
} 
considering faculty outcomes, only Native Americans are less likely to get tenure track appointments whereas Blacks and Hispanics are more likely to transition to assistant professorships. Asians have increased their representation in tenure-track faculty for the two most recent cohorts. In contrast, women are proportionally overrepresented at college completion but then lose representation between bachelor's degree receipt and completion of a doctoral program. Women once again lose proportional representation between receipt of a doctoral degree and appointment as an assistant professor, possibly at the final transition between postdoctoral work and faculty appointment.

When we examined academic career outcomes using the SDR, we find some notable, significant demographic differences in the probability of getting a tenure-track job, receiving tenure, and receiving federal research support. After including a full set of demographic, PhD, and family characteristics, women are no different than men in obtaining a tenure track job. In contrast, Blacks and Hispanics are $9-10$ percent more likely to get a tenure track job than Whites. However, Native Americans, Asians, and Foreign-born Blacks are less likely to get jobs on the tenure track. The available data do not explain these differences, but we offer three potential explanations. First, these groups may choose other career paths besides academia and are thus less likely to take tenure track jobs. Second, most tenure track biomedical jobs require lengthy postdoctoral fellowships. These groups may discover that academic science is not a good career match and choose different jobs. Finally, there may be discrimination in the hiring process that works to the disadvantage of Asians and foreign-born Blacks. However, if discrimination were at issue, we would expect it to also appear for native-born Blacks and foreign-born Asians, which is not supported by our results.

Next, we turned our attention to demographic differences in the probability of getting tenure. In our initial models women were less likely to get tenure than men, but this result is no longer statistically significant after controlling for employer characteristics and academic productivity. Similar to the tenure track analysis, we find that Blacks are significantly more likely to get tenure than Whites and foreign-born Blacks. Foreign-born scientists are over 20 percent less likely to get tenure after controlling for publications, employer characteristics, and government support. 
Finally, we find few demographic differences in the probability of getting NIH or NSF funding. Women and Asians are more likely to get NIH funding after controlling for the full set of observable characteristics relative to men and Whites. Foreign-born Asians are significantly less likely to receive NSF funding. No other demographic characteristics are statistically significant in these regressions. We must note that these estimates do not account for the size or type of NIH or NSF funding. Significant demographic differences may exist along these dimensions, but the SDR data do not allow us to investigate this possibility.

Taken together, these results suggest different avenues for policy intervention to promote diversity in the biomedical workforce. To increase the representation of Blacks, Hispanics, and Native Americans in academic biomedicine, policies should be implemented to promote increased high school and college graduation in the sciences, and to encourage members of these racial/ethnic groups to complete doctoral programs in biomedical science. A recent study by Adelman suggests that the quality of high school curriculum (with high academic intensity) increases the likelihood that Blacks and Hispanics will graduate from college. In particular, those students who take advanced mathematics courses in high school are more likely to graduate from college (Adelman 1999). Likewise, a National Research Council report (NRC 2000) concluded that to promote diversity in the biomedical research workforce it was necessary to intervene early in the educational process: "The committee urges the agencies to focus their attention on improvements in opportunities for minorities at the secondary school level (or earlier), seeking legislative authority to do so, if necessary."

Once Blacks and Hispanics obtain tenure track jobs, they progress through their academic careers and receive federal funding for their research. Native Americans and Asians face some difficulty in getting tenure track positions, but do receive tenure at the same rate after controlling for productivity measures.

When considering the transition data along with the SDR data on the probability of members of racial/ethnic and gender groups in receiving a tenure track job, it is interesting to note only for women do we see differences. Women are equally likely to receive a tenure track job as men, but as shown by the aggregate data presented above, women are lost in the transition between graduate school and tenure track position. Related research by Ginther and 
Kahn (2009) finds that women with children are less likely to advance into academic careers beyond the postdoc. Thus, policies designed to help parents transition from the postdoc to faculty appointment would seem to be in order, as recommended recently by the National Academies (NAS 2007), including increased access to childcare; paid parental leave for faculty, postdocs, and graduate students; and mandated tenure clock extension policies. 


\section{APPENDIX TABLES}

Table A1: Means, Standard Deviations and Variable Definitions 1986 - 2006 Survey of Doctorate Recipients Samples

\begin{tabular}{|c|c|c|c|c|c|}
\hline & $\begin{array}{c}\text { Tenure } \\
\text { Track } \\
\text { Sample }\end{array}$ & $\begin{array}{l}\text { Tenure } \\
\text { Sample }\end{array}$ & & $\begin{array}{c}\text { Tenure } \\
\text { Track } \\
\text { Sample }\end{array}$ & $\begin{array}{l}\text { Tenure } \\
\text { Sample }\end{array}$ \\
\hline Outcome Variables: & & & $\begin{array}{l}\text { Time Varying } \\
\text { Characteristics Measured: }\end{array}$ & $\frac{\frac{\text { Within } 7}{\text { Years of }}}{\underline{\text { PhD: }}}$ & $\frac{\frac{\text { Within 11 }}{\text { Years of }}}{\underline{\text { PhD: }}}$ \\
\hline \multirow[t]{2}{*}{ Tenure Track within 7 Years of PhD $=1$} & 0.3043 & 0.7179 & Married = 1 & 0.7505 & 0.7792 \\
\hline & {$[.4602]$} & {$[.4502]$} & & {$[.4328]$} & {$[.415]$} \\
\hline \multirow[t]{2}{*}{ Tenured within 10 Years of PhD = 1} & 0.1685 & 0.3715 & Total Number Children & 0.9911 & 1.1778 \\
\hline & {$[.3744]$} & {$[.4835]$} & & [1.1064] & [1.1592] \\
\hline \multirow[t]{2}{*}{$\mathrm{NIH}$ funding within 10 Years of $\mathrm{PhD}=1$} & 0.1797 & 0.4295 & Children $<6$ Years $=1$ & 0.4518 & 0.3182 \\
\hline & {$[.384]$} & {$[.4952]$} & & {$[.4978]$} & {$[.4661]$} \\
\hline \multirow[t]{2}{*}{ NSF funding within 10 Years of PhD $=1$} & 0.0606 & 0.1455 & Cumulative Employers & & 1.7614 \\
\hline & {$[.2387]$} & {$[.3528]$} & & & {$[.9087]$} \\
\hline Demographic and PhD Characteristics: & & & Cumulative Papers & & 17.0931 \\
\hline \multirow[t]{2}{*}{$\overline{\text { Female }=1}$} & 0.4396 & 0.4482 & Written & & [18.67] \\
\hline & {$[.4964]$} & {$[.4975]$} & Cumulative Publications & & 14.0268 \\
\hline \multirow[t]{2}{*}{ Age at PhD } & 32.9726 & 33.075 & & & [15.8223] \\
\hline & {$[5.4795]$} & [5.5439] & Employer Characteristics: & & \\
\hline \multirow[t]{2}{*}{ Year of PhD } & 88.1213 & 88.0812 & Private University = 1 & & 0.2571 \\
\hline & [2.3509] & [2.3355] & & & {$[.4373]$} \\
\hline \multirow[t]{2}{*}{ White $=1$} & 0.7516 & 0.7509 & Research I = 1 & & 0.3805 \\
\hline & [.4322] & {$[.4327]$} & & & {$[.4858]$} \\
\hline \multirow[t]{2}{*}{ Black = 1} & 0.0588 & 0.0661 & Liberal Arts I = 1 & & 0.1789 \\
\hline & {$[.2353]$} & {$[.2485]$} & & & {$[.3835]$} \\
\hline \multirow[t]{2}{*}{ Asian = 1} & 0.1201 & 0.0973 & Medical School = 1 & & 0.3341 \\
\hline & {$[.3252]$} & {$[.2965]$} & & & {$[.4719]$} \\
\hline \multirow[t]{2}{*}{ Native American $=1$} & 0.0166 & 0.0179 & Academic Fields: & & \\
\hline & {$[.1279]$} & {$[.1325]$} & Biochemistry = 1 & 0.1519 & 0.1366 \\
\hline \multirow[t]{2}{*}{ Hispanic = 1} & 0.0525 & 0.0679 & & {$[.359]$} & {$[.3436]$} \\
\hline & {$[.2231]$} & {$[.2516]$} & Microbiology = 1 & 0.0732 & 0.0527 \\
\hline \multirow[t]{2}{*}{ Other Race $=1$} & 0.0004 & & & {$[.2605]$} & {$[.2235]$} \\
\hline & {$[.0192]$} & & Zoology & 0.0636 & 0.0598 \\
\hline \multirow[t]{2}{*}{ Foreign Born = 1} & 0.1505 & 0.133 & & {$[.2441]$} & {$[.2373]$} \\
\hline & {$[.3576]$} & {$[.3398]$} & Health Sciences & 0.2081 & 0.2643 \\
\hline \multirow[t]{2}{*}{ Ph.D. from Research I = 1} & 0.722 & 0.7268 & & {$[.406]$} & {$[.4411]$} \\
\hline & {$[.4481]$} & {$[.4458]$} & Observations & 2705 & 1120 \\
\hline \multirow[t]{2}{*}{ Ph.D. from Research II = 1} & 0.0858 & 0.075 & & & \\
\hline & {$[.2801]$} & {$[.2635]$} & & & \\
\hline \multirow[t]{2}{*}{ Ph.D. from Doctorate I =1 } & 0.0473 & 0.0589 & & & \\
\hline & {$[.2124]$} & {$[.2356]$} & & & \\
\hline \multirow[t]{2}{*}{ Ph.D. from Doctorate II = 1} & 0.0288 & 0.0268 & & & \\
\hline & {$[.1674]$} & {$[.1615]$} & & & \\
\hline
\end{tabular}

Note: Standard Deviations appear in brackets. 
Table A2: Demographic Differences in the Probability of Receiving a Tenure Track Job within 7 Years of Doctorate,

\begin{tabular}{|c|c|c|c|c|c|}
\hline & 1 & 2 & 3 & 4 & 5 \\
\hline \multirow[t]{2}{*}{ Female } & $0.033^{\star}$ & 0.008 & 0.006 & 0.024 & 0.023 \\
\hline & [0.018] & [0.019] & [0.019] & [0.019] & [0.019] \\
\hline \multirow[t]{2}{*}{ Age at PhD } & $0.007^{\star \star \star}$ & 0.001 & 0.002 & 0.002 & 0.002 \\
\hline & [0.002] & [0.002] & [0.002] & [0.002] & [0.002] \\
\hline \multirow[t]{2}{*}{ Year of PhD } & -0.006 & -0.006 & -0.005 & -0.006 & -0.006 \\
\hline & {$[0.004]$} & {$[0.004]$} & {$[0.004]$} & [0.004] & [0.004] \\
\hline \multirow[t]{2}{*}{ Black } & $0.067^{*}$ & 0.044 & 0.043 & 0.058 & $0.092^{\star *}$ \\
\hline & [0.040] & [0.039] & [0.039] & {$[0.040]$} & [0.045] \\
\hline \multirow[t]{2}{*}{ Asian } & $-0.069 * *$ & $-0.068^{\star \star}$ & $-0.072^{\star \star}$ & $-0.068 * \star$ & $-0.082^{*}$ \\
\hline & [0.032] & [0.032] & [0.032] & [0.032] & [0.044] \\
\hline \multirow[t]{2}{*}{ Native American } & -0.105 & $-0.126^{\star}$ & $-0.126^{\star}$ & -0.108 & -0.108 \\
\hline & [0.061] & [0.058] & {$[0.057]$} & {$[0.062]$} & {$[0.062]$} \\
\hline \multirow[t]{2}{*}{ Hispanic } & $0.115^{\star \star \star}$ & $0.124^{\star \star \star}$ & $0.124^{\star \star \star}$ & $0.126^{\star \star \star}$ & $0.101^{* *}$ \\
\hline & [0.043] & [0.043] & [0.043] & [0.043] & {$[0.047]$} \\
\hline \multirow[t]{2}{*}{ Foreign Born } & $-0.055^{\star}$ & $-0.059 * \star$ & $-0.055^{\star}$ & $-0.065^{\star \star}$ & -0.065 \\
\hline & [0.029] & [0.029] & [0.029] & [0.029] & [0.040] \\
\hline \multirow[t]{2}{*}{ Foreign Born*Black } & & & & & $-0.161^{*}$ \\
\hline & & & & & {$[0.070]$} \\
\hline \multirow[t]{2}{*}{ Foreign Born*Asian } & & & & & 0.023 \\
\hline & & & & & {$[0.076]$} \\
\hline \multirow[t]{2}{*}{ Foreign Born*Hispanic } & & & & & 0.147 \\
\hline & & & & & [0.122] \\
\hline \multirow[t]{2}{*}{ Ph.D. from Research I } & & & 0.042 & 0.039 & 0.042 \\
\hline & & & {$[0.028]$} & {$[0.028]$} & {$[0.028]$} \\
\hline \multirow[t]{2}{*}{ Ph.D. from Research II } & & & -0.001 & -0.004 & -0.001 \\
\hline & & & {$[0.042]$} & {$[0.041]$} & {$[0.042]$} \\
\hline \multirow[t]{2}{*}{ Ph.D. from Doctorate I } & & & 0.071 & 0.067 & 0.066 \\
\hline & & & [0.053] & [0.053] & [0.053] \\
\hline \multirow[t]{2}{*}{ Ph.D. from Doctorate II } & & & -0.026 & -0.028 & -0.027 \\
\hline & & & [0.059] & [0.058] & [0.058] \\
\hline \multirow[t]{2}{*}{ Biochemistry } & & -0.021 & -0.02 & -0.018 & -0.019 \\
\hline & & {$[0.026]$} & {$[0.026]$} & {$[0.026]$} & {$[0.027]$} \\
\hline \multirow[t]{2}{*}{ Microbiology } & & $-0.065^{\star}$ & $-0.062^{\star}$ & $-0.063^{\star}$ & $-0.066^{\star \star}$ \\
\hline & & [0.033] & {$[0.034]$} & {$[0.034]$} & {$[0.033]$} \\
\hline \multirow[t]{2}{*}{ Zoology } & & 0 & -0.001 & 0.006 & 0.004 \\
\hline & & [0.038] & [0.038] & {$[0.038]$} & {$[0.038]$} \\
\hline \multirow[t]{2}{*}{ Health Sciences } & & $0.171 * \star \star$ & $0.168^{\star \star \star}$ & $0.168^{\star \star \star}$ & $0.170 * * \star$ \\
\hline & & {$[0.027]$} & {$[0.027]$} & {$[0.027]$} & {$[0.028]$} \\
\hline \multirow[t]{2}{*}{ Married } & & & & $0.086^{\star * *}$ & $0.086^{\star \star \star}$ \\
\hline & & & & {$[0.023]$} & {$[0.023]$} \\
\hline \multirow[t]{2}{*}{ Children $<6$} & & & & 0.003 & -0.001 \\
\hline & & & & {$[0.028]$} & {$[0.028]$} \\
\hline \multirow[t]{2}{*}{ Total Children } & & & & 0.014 & 0.016 \\
\hline & & & & [0.012] & [0.012] \\
\hline Observations & 2704 & 2704 & 2704 & 2704 & 2704 \\
\hline
\end{tabular}

Notes: Probit model coefficients report marginal effects. Robust Standard errors in brackets.

***Significant at $1 \% ;{ }^{* *}$ Significant at $5 \%$; Significant at $10 \%$. 
Table A3: Demographic Differences in the Probability of Receiving Tenure within 10 Years of Doctorate,

\begin{tabular}{|c|c|c|c|c|c|}
\hline & 1 & 2 & 3 & 4 & 5 \\
\hline \multirow[t]{2}{*}{ Female } & $-0.092^{\star \star}$ & $-0.074^{\star \star}$ & -0.063 & -0.063 & -0.066 \\
\hline & [0.036] & {$[0.037]$} & [0.039] & {$[0.051]$} & [0.051] \\
\hline \multirow[t]{2}{*}{ Age at $\mathrm{PhD}$} & $0.015^{\star \star \star}$ & $0.017^{\star \star \star}$ & $0.016^{\star \star \star}$ & 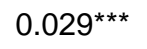 & $0.029 * * *$ \\
\hline & [0.004] & [0.004] & {$[0.004]$} & {$[0.006]$} & {$[0.006]$} \\
\hline \multirow[t]{2}{*}{ Year of PhD } & 0.002 & 0.002 & -0.001 & -0.007 & -0.008 \\
\hline & {$[0.007]$} & {$[0.007]$} & {$[0.007]$} & [0.010] & [0.010] \\
\hline \multirow[t]{2}{*}{ African American } & 0.070 & 0.071 & 0.055 & 0.150 & $0.223^{\star \star}$ \\
\hline & [0.073] & [0.073] & [0.075] & [0.095] & [0.100] \\
\hline \multirow[t]{2}{*}{ Asian } & -0.042 & -0.03 & 0.005 & 0.067 & 0.005 \\
\hline & [0.069] & {$[0.070]$} & {$[0.075]$} & [0.093] & [0.128] \\
\hline \multirow[t]{2}{*}{ Native American } & -0.130 & -0.131 & $-0.201^{*}$ & -0.215 & -0.218 \\
\hline & [0.102] & [0.103] & [0.086] & [0.140] & [0.140] \\
\hline \multirow[t]{2}{*}{ Hispanic } & 0.042 & 0.034 & 0.002 & 0.112 & 0.113 \\
\hline & {$[0.067]$} & {$[0.066]$} & [0.069] & [0.092] & [0.102] \\
\hline \multirow[t]{2}{*}{ Foreign Born } & $-0.117^{\star \star}$ & $-0.129 \star *$ & $-0.127^{\star \star}$ & $-0.216^{\star \star *}$ & $-0.194^{*}$ \\
\hline & {$[0.055]$} & {$[0.054]$} & {$[0.055]$} & [0.073] & [0.106] \\
\hline \multirow[t]{2}{*}{ Foreign Born`Black } & & & & & -0.325 \\
\hline & & & & & [0.167] \\
\hline \multirow[t]{2}{*}{ Foreign BornAsian } & & & & & 0.08 \\
\hline & & & & & [0.192] \\
\hline \multirow[t]{2}{*}{ Foreign Born*Hispanic } & & & & & -0.016 \\
\hline & & & & & {$[0.246]$} \\
\hline \multirow[t]{2}{*}{ Ph.D. from Research I } & 0.075 & 0.075 & 0.055 & 0.017 & 0.021 \\
\hline & {$[0.056]$} & {$[0.056]$} & [0.058] & {$[0.079]$} & {$[0.079]$} \\
\hline \multirow[t]{2}{*}{ Ph.D. from Research II } & 0.064 & 0.067 & 0.028 & 0.038 & 0.056 \\
\hline & {$[0.085]$} & {$[0.085]$} & {$[0.087]$} & [0.110] & [0.110] \\
\hline \multirow[t]{2}{*}{ Ph.D. from Doctorate I } & 0.045 & 0.041 & 0.057 & 0.077 & 0.075 \\
\hline & {$[0.096]$} & [0.095] & [0.102] & {$[0.130]$} & {$[0.130]$} \\
\hline \multirow[t]{2}{*}{ Ph.D. from Doctorate II } & 0.097 & 0.102 & 0.098 & 0.018 & 0.018 \\
\hline & [0.120] & {$[0.120]$} & [0.128] & [0.155] & [0.155] \\
\hline \multirow[t]{2}{*}{ Biochemistry } & -0.063 & -0.052 & -0.041 & -0.04 & -0.045 \\
\hline & {$[0.050]$} & {$[0.051]$} & [0.053] & [0.068] & [0.068] \\
\hline \multirow[t]{2}{*}{ Microbiology } & -0.094 & -0.092 & -0.065 & -0.073 & -0.091 \\
\hline & {$[0.070]$} & {$[0.070]$} & {$[0.076]$} & [0.105] & [0.105] \\
\hline \multirow[t]{2}{*}{ Zoology } & 0.113 & 0.107 & 0.069 & 0.044 & 0.039 \\
\hline & [0.073] & {$[0.073]$} & {$[0.075]$} & {$[0.090]$} & {$[0.090]$} \\
\hline \multirow[t]{2}{*}{ Health Sciences } & $0.140 * \star \star$ & $0.130^{\star \star \star}$ & $0.178^{\star \star \star}$ & $0.289^{\star \star \star}$ & $0.296^{\star \star \star}$ \\
\hline & [0.049] & [0.049] & [0.052] & [0.061] & [0.061] \\
\hline \multirow[t]{2}{*}{ Married } & & -0.011 & 0.002 & -0.064 & -0.057 \\
\hline & & {$[0.046]$} & {$[0.047]$} & [0.063] & [0.064] \\
\hline \multirow[t]{2}{*}{ Total Children } & & $0.046^{\star *}$ & $0.040 * *$ & $0.052^{\star \star}$ & $0.054^{\star \star}$ \\
\hline & & [0.018] & [0.019] & [0.025] & [0.025] \\
\hline \multirow[t]{2}{*}{ Children $<6$} & & -0.043 & -0.023 & -0.031 & -0.036 \\
\hline & & [0.044] & [0.046] & [0.060] & [0.060] \\
\hline
\end{tabular}


Table A3 (continued): Demographic Differences in the Probability of Receiving Tenure within 10 Years of Doctorate, 1985 - 2006 Survey of Doctorate Recipient

\begin{tabular}{|c|c|c|c|c|c|}
\hline & 1 & 2 & 3 & 4 & 5 \\
\hline \multirow[t]{2}{*}{ Cumulative Employers } & & & $-0.164^{\star \star *}$ & $-0.119 * * *$ & $-0.120 * \star \star$ \\
\hline & & & [0.022] & [0.029] & {$[0.029]$} \\
\hline \multirow[t]{2}{*}{ Private University } & & & $-0.066^{\star}$ & -0.083 & -0.084 \\
\hline & & & {$[0.040]$} & {$[0.052]$} & {$[0.052]$} \\
\hline \multirow[t]{2}{*}{ Research I } & & & 0.011 & $-0.176^{\star \star *}$ & $-0.179 * * \star$ \\
\hline & & & {$[0.040]$} & {$[0.052]$} & [0.052] \\
\hline \multirow[t]{2}{*}{ Liberal Arts I } & & & $0.178^{\star \star \star}$ & $0.111^{*}$ & $0.114^{\star}$ \\
\hline & & & [0.053] & [0.065] & [0.065] \\
\hline \multirow[t]{2}{*}{ Medical School } & & & $-0.170^{\star \star \star}$ & $-0.275^{\star \star *}$ & $-0.277^{\star * \star}$ \\
\hline & & & [0.037] & [0.048] & [0.049] \\
\hline \multirow{2}{*}{$\begin{array}{l}\text { Government Support } \\
\text { in Current Year }\end{array}$} & & & & $-0.231^{\star \star \star}$ & $-0.231^{\star \star \star}$ \\
\hline & & & & {$[0.066]$} & {$[0.066]$} \\
\hline \multirow{2}{*}{$\begin{array}{l}\text { Cumulative Years of } \\
\text { Government Support }\end{array}$} & & & & $0.145^{\star \star \star}$ & $0.148^{\star \star \star}$ \\
\hline & & & & {$[0.026]$} & {$[0.026]$} \\
\hline \multirow[t]{2}{*}{ Cumulative Papers } & & & & -0.001 & -0.001 \\
\hline & & & & {$[0.002]$} & {$[0.002]$} \\
\hline \multirow[t]{2}{*}{ Cumulative Publications } & & & & $0.007^{\star \star *}$ & $0.007^{* * *}$ \\
\hline & & & & {$[0.002]$} & {$[0.002]$} \\
\hline Observations & 883 & 883 & 880 & 666 & 666 \\
\hline
\end{tabular}

Notes: Probit model coefficients report marginal effects. Robust Standard errors in brackets.

$* * *$ Significant at $1 \% ; *$ Significant at $5 \%$; ${ }^{*}$ Significant at $10 \%$. 
Table A4: Demographic Differences in the Probability of Receiving NIH Funding within 10 Years of Doctorate, 1985 - 2006 Survey of Doctorate Recipients

\begin{tabular}{|c|c|c|c|c|c|}
\hline & 1 & 2 & 3 & 4 & 5 \\
\hline \multirow[t]{2}{*}{ Female } & $0.061^{\star}$ & 0.062 & 0.062 & $0.085^{\star \star}$ & $0.084^{\star *}$ \\
\hline & [0.033] & [0.038] & {$[0.040]$} & {$[0.041]$} & {$[0.041]$} \\
\hline \multirow[t]{2}{*}{ Age at PhD } & $-0.017^{\star \star \star}$ & $-0.019 \star \star \star *$ & $-0.015^{\star \star \star}$ & $-0.013^{\star \star \star}$ & $-0.013^{\star \star \star}$ \\
\hline & [0.003] & [0.004] & {$[0.004]$} & [0.004] & [0.005] \\
\hline \multirow[t]{2}{*}{ Year of PhD } & -0.005 & -0.004 & -0.001 & -0.010 & -0.010 \\
\hline & [0.007] & [0.007] & [0.008] & [0.008] & [0.008] \\
\hline \multirow[t]{2}{*}{ African American } & $-0.126^{\star \star}$ & -0.083 & -0.023 & -0.010 & -0.011 \\
\hline & [0.058] & [0.072] & [0.078] & [0.080] & {$[0.086]$} \\
\hline \multirow[t]{2}{*}{ Asian } & -0.081 & -0.055 & -0.079 & -0.071 & -0.124 \\
\hline & [0.061] & [0.068] & [0.071] & [0.072] & [0.100] \\
\hline \multirow[t]{2}{*}{ Native American } & 0.022 & 0.113 & $0.220^{\star}$ & $0.242^{\star}$ & $0.243^{\star}$ \\
\hline & [0.113] & [0.126] & [0.127] & [0.127] & [0.127] \\
\hline \multirow[t]{2}{*}{ Hispanic } & $-0.103^{\star}$ & -0.059 & 0.026 & 0.035 & 0.063 \\
\hline & [0.059] & {$[0.067]$} & {$[0.073]$} & {$[0.074]$} & [0.082] \\
\hline \multirow[t]{2}{*}{ Foreign Born } & 0.037 & 0.027 & 0.004 & -0.009 & -0.012 \\
\hline & {$[0.056]$} & [0.062] & {$[0.066]$} & {$[0.066]$} & [0.095] \\
\hline \multirow[t]{2}{*}{ Foreign Born*Black } & & & & & 0.010 \\
\hline & & & & & {$[0.243]$} \\
\hline \multirow[t]{2}{*}{ Foreign Born`Asian } & & & & & 0.083 \\
\hline & & & & & [0.162] \\
\hline \multirow[t]{2}{*}{ Foreign Born*Hispanic } & & & & & -0.127 \\
\hline & & & & & {$[0.176]$} \\
\hline \multirow[t]{2}{*}{ Ph.D. from Research I } & -0.002 & -0.053 & -0.053 & -0.072 & -0.072 \\
\hline & {$[0.049]$} & {$[0.058]$} & {$[0.060]$} & [0.061] & {$[0.061]$} \\
\hline \multirow[t]{2}{*}{ Ph.D. from Research II } & $-0.117^{\star}$ & $-0.174^{\star \star}$ & $-0.149 *$ & $-0.150^{*}$ & $-0.151^{*}$ \\
\hline & {$[0.067]$} & {$[0.072]$} & {$[0.078]$} & {$[0.079]$} & {$[0.079]$} \\
\hline \multirow[t]{2}{*}{ Ph.D. from Doctorate I } & $-0.160 * \star$ & $-0.185^{\star \star}$ & -0.133 & -0.156 & -0.158 \\
\hline & {$[0.071]$} & {$[0.080]$} & {$[0.092]$} & {$[0.090]$} & {$[0.090]$} \\
\hline \multirow[t]{2}{*}{ Ph.D. from Doctorate II } & $-0.178^{\star}$ & $-0.244^{\star \star}$ & $-0.197^{\star}$ & $-0.221^{*}$ & $-0.222^{*}$ \\
\hline & {$[0.089]$} & {$[0.086]$} & [0.101] & {$[0.096]$} & {$[0.096]$} \\
\hline \multirow[t]{2}{*}{ Biochemistry } & $0.125^{\star \star \star}$ & $0.117^{\star \star}$ & $0.130^{\star *}$ & $0.133^{\star \star}$ & $0.132^{\star \star}$ \\
\hline & {$[0.046]$} & {$[0.052]$} & {$[0.055]$} & {$[0.055]$} & {$[0.056]$} \\
\hline \multirow[t]{2}{*}{ Microbiology } & 0.054 & 0.05 & 0.118 & 0.112 & 0.112 \\
\hline & {$[0.070]$} & {$[0.078]$} & [0.081] & {$[0.081]$} & {$[0.082]$} \\
\hline \multirow[t]{2}{*}{ Zoology } & $-0.143^{\star \star}$ & -0.092 & -0.038 & -0.057 & -0.056 \\
\hline & [0.061] & {$[0.073]$} & {$[0.080]$} & {$[0.080]$} & {$[0.080]$} \\
\hline \multirow[t]{2}{*}{ Health Sciences } & -0.015 & 0.023 & 0.077 & 0.058 & 0.057 \\
\hline & {$[0.042]$} & [0.051] & [0.054] & [0.055] & [0.055] \\
\hline \multirow[t]{2}{*}{ Married } & & $0.097^{\star *}$ & $0.103^{\star \star}$ & $0.094^{*}$ & $0.094^{\star}$ \\
\hline & & [0.045] & [0.047] & [0.047] & [0.047] \\
\hline \multirow[t]{2}{*}{ Total Children } & & $-0.047^{\star \star}$ & $-0.050 * \star$ & $-0.052^{\star \star}$ & $-0.053^{\star \star *}$ \\
\hline & & [0.019] & {$[0.020]$} & {$[0.020]$} & {$[0.020]$} \\
\hline \multirow[t]{2}{*}{ Children $<6$} & & 0.049 & 0.049 & 0.054 & 0.055 \\
\hline & & {$[0.046]$} & [0.048] & [0.049] & [0.049] \\
\hline
\end{tabular}


Table A4 (continued): Demographic Differences in the Probability of Receiving NIH Funding within 10 Years of Doctorate, 1985 - 2006 Survey of Doctorate Recipients

\begin{tabular}{|c|c|c|c|c|c|}
\hline & 1 & 2 & 3 & 4 & 5 \\
\hline \multirow[t]{2}{*}{ Cumulative Employers } & & & $-0.053^{\star \star}$ & $-0.048^{\star *}$ & $-0.047^{\star *}$ \\
\hline & & & {$[0.021]$} & {$[0.021]$} & [0.021] \\
\hline \multirow[t]{2}{*}{ Private University } & & & 0.066 & $0.075^{\star}$ & $0.073^{*}$ \\
\hline & & & [0.043] & [0.044] & [0.044] \\
\hline \multirow[t]{2}{*}{ Research I } & & & $0.179 * \star \star$ & $0.161^{\star \star *}$ & $0.161^{\star \star \star}$ \\
\hline & & & {$[0.040]$} & {$[0.041]$} & {$[0.041]$} \\
\hline \multirow[t]{2}{*}{ Liberal Arts I } & & & $-0.159 \star \star \star$ & $-0.127^{\star \star}$ & $-0.126^{\star \star}$ \\
\hline & & & {$[0.051]$} & {$[0.053]$} & [0.054] \\
\hline \multirow[t]{2}{*}{ Medical School } & & & 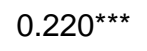 & $0.215^{\star \star \star}$ & $0.213^{\star * \star}$ \\
\hline & & & {$[0.039]$} & {$[0.040]$} & {$[0.040]$} \\
\hline \multirow[t]{2}{*}{ Cumulative Papers } & & & & 0.000 & 0.000 \\
\hline & & & & {$[0.001]$} & {$[0.001]$} \\
\hline \multirow[t]{2}{*}{ Cumulative Publications } & & & & $0.005^{\star \star \star}$ & $0.005^{\star \star \star}$ \\
\hline & & & & & [0.002] \\
\hline Observations & 1120 & 883 & 880 & 880 & 880 \\
\hline
\end{tabular}

Notes: Probit model coefficients report marginal effects. Robust Standard errors in brackets.

***Significant at $1 \%$; ** Significant at $5 \%$; Significant at $10 \%$. 
Table A5: Demographic Differences in the Probability of Receiving NSF Funding within 10 Years of Doctorate, $1985-2003$ Survey of Doctorate Recipients

\begin{tabular}{|c|c|c|c|c|c|}
\hline & 1 & 2 & 3 & 4 & 5 \\
\hline \multirow[t]{2}{*}{ Female } & -0.001 & -0.001 & 0.002 & 0.008 & 0.01 \\
\hline & {$[0.018]$} & [0.020] & [0.018] & [0.018] & [0.018] \\
\hline \multirow[t]{2}{*}{ Age at PhD } & $-0.004^{\star}$ & -0.002 & -0.003 & -0.002 & -0.002 \\
\hline & {$[0.002]$} & [0.003] & {$[0.002]$} & {$[0.002]$} & {$[0.002]$} \\
\hline \multirow[t]{2}{*}{ Year of PhD } & -0.004 & -0.001 & -0.001 & -0.003 & -0.002 \\
\hline & [0.004] & [0.004] & [0.004] & [0.004] & {$[0.004]$} \\
\hline \multirow[t]{2}{*}{ African American } & -0.002 & -0.003 & -0.025 & -0.023 & -0.033 \\
\hline & [0.039] & {$[0.046]$} & [0.032] & [0.032] & {$[0.029]$} \\
\hline \multirow[t]{2}{*}{ Asian } & -0.023 & -0.028 & -0.023 & -0.022 & 0.037 \\
\hline & [0.029] & [0.031] & {$[0.027]$} & {$[0.027]$} & {$[0.052]$} \\
\hline \multirow[t]{2}{*}{ Native American } & $0.187^{\star \star}$ & $0.214^{\star \star}$ & $0.159^{*}$ & $0.169^{*}$ & $0.172^{\star}$ \\
\hline & [0.115] & {$[0.138]$} & [0.123] & [0.125] & {$[0.126]$} \\
\hline \multirow[t]{2}{*}{ Hispanic } & -0.007 & -0.003 & -0.023 & -0.022 & -0.024 \\
\hline & [0.031] & [0.034] & {$[0.025]$} & [0.025] & {$[0.026]$} \\
\hline \multirow[t]{2}{*}{ Foreign Born } & -0.036 & -0.035 & -0.031 & -0.034 & -0.008 \\
\hline & {$[0.025]$} & [0.027] & [0.023] & [0.022] & {$[0.037]$} \\
\hline \multirow[t]{2}{*}{ Foreign BornBlack } & & & & & 0.161 \\
\hline & & & & & {$[0.261]$} \\
\hline \multirow[t]{2}{*}{ Foreign BornAsian } & & & & & $-0.073^{\star \star}$ \\
\hline & & & & & {$[0.020]$} \\
\hline \multirow[t]{2}{*}{ Foreign Born*Hispanic } & & & & & -0.002 \\
\hline & & & & & {$[0.076]$} \\
\hline \multirow[t]{2}{*}{ Ph.D. from Research I } & 0.036 & 0.036 & 0.02 & 0.016 & 0.015 \\
\hline & [0.025] & {$[0.028]$} & {$[0.027]$} & [0.028] & {$[0.027]$} \\
\hline \multirow[t]{2}{*}{ Ph.D. from Research II } & 0.005 & 0.001 & -0.012 & -0.012 & -0.015 \\
\hline & {$[0.043]$} & {$[0.047]$} & [0.038] & {$[0.037]$} & {$[0.035]$} \\
\hline \multirow[t]{2}{*}{ Ph.D. from Doctorate I } & -0.049 & -0.076 & -0.064 & -0.064 & -0.062 \\
\hline & {$[0.037]$} & [0.029] & {$[0.024]$} & [0.024] & {$[0.023]$} \\
\hline \multirow[t]{2}{*}{ Ph.D. from Doctorate II } & 0.058 & 0.075 & 0.045 & 0.039 & 0.036 \\
\hline & [0.079] & {$[0.090]$} & {$[0.077]$} & {$[0.073]$} & {$[0.071]$} \\
\hline \multirow[t]{2}{*}{ Biochemistry } & -0.001 & -0.005 & 0.004 & 0.002 & 0.007 \\
\hline & {$[0.022]$} & [0.024] & [0.023] & {$[0.023]$} & {$[0.023]$} \\
\hline \multirow[t]{2}{*}{ Microbiology } & -0.016 & -0.012 & -0.005 & -0.008 & -0.006 \\
\hline & [0.030] & [0.034] & [0.033] & [0.032] & {$[0.031]$} \\
\hline \multirow[t]{2}{*}{ Zoology } & 0.003 & -0.009 & -0.016 & -0.017 & -0.019 \\
\hline & [0.032] & [0.033] & {$[0.027]$} & {$[0.026]$} & {$[0.025]$} \\
\hline \multirow[t]{2}{*}{ Health Sciences } & $-0.169 \star \star \star$ & $-0.180^{\star \star \star}$ & 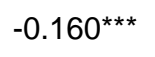 & $-0.161^{\star \star \star}$ & $-0.159^{\star \star \star}$ \\
\hline & {$[0.017]$} & [0.018] & [0.018] & [0.018] & {$[0.018]$} \\
\hline \multirow[t]{2}{*}{ Married } & & 0.014 & 0.025 & 0.023 & 0.021 \\
\hline & & [0.024] & {$[0.020]$} & [0.020] & {$[0.020]$} \\
\hline \multirow[t]{2}{*}{ Total Children } & & -0.002 & -0.003 & -0.003 & -0.004 \\
\hline & & {$[0.010]$} & [0.009] & [0.009] & {$[0.009]$} \\
\hline \multirow[t]{2}{*}{ Children $<6$} & & -0.005 & 0.004 & 0.005 & 0.007 \\
\hline & & [0.023] & {$[0.022]$} & {$[0.022]$} & {$[0.022]$} \\
\hline
\end{tabular}


Table A5 (continued): Demographic Differences in the Probability of Receiving NSF Funding within 10 Years of Doctorate, 1985 - 2003 Survey of Doctorate Recipients

\begin{tabular}{|c|c|c|c|c|c|}
\hline & 1 & 2 & 3 & 4 & 5 \\
\hline \multirow[t]{2}{*}{ Cumulative Employers } & & & -0.017 & -0.016 & -0.015 \\
\hline & & & {$[0.011]$} & {$[0.011]$} & [0.010] \\
\hline \multirow[t]{2}{*}{ Private University } & & & -0.011 & -0.01 & -0.01 \\
\hline & & & [0.019] & {$[0.019]$} & [0.019] \\
\hline \multirow[t]{2}{*}{ Research I } & & & 0.028 & 0.023 & 0.022 \\
\hline & & & {$[0.021]$} & {$[0.020]$} & {$[0.020]$} \\
\hline \multirow[t]{2}{*}{ Liberal Arts I } & & & -0.002 & 0.004 & 0.001 \\
\hline & & & {$[0.024]$} & {$[0.025]$} & [0.024] \\
\hline \multirow[t]{2}{*}{ Medical School } & & & $-0.112^{\star \star \star}$ & $-0.113^{\star \star \star}$ & $-0.109 * \star \star$ \\
\hline & & & {$[0.021]$} & {$[0.021]$} & [0.021] \\
\hline \multirow[t]{2}{*}{ Cumulative Papers } & & & & 0 & 0 \\
\hline & & & & [0.001] & [0.001] \\
\hline \multirow[t]{2}{*}{ Cumulative Publications } & & & & $0.001 *$ & $0.001^{*}$ \\
\hline & & & & {$[0.000]$} & [0.001] \\
\hline Observations & 1120 & 883 & 880 & 880 & 880 \\
\hline
\end{tabular}

Notes: Probit model coefficients report marginal effects. Robust Standard errors in brackets.

***Significant at $1 \%$; ** Significant at $5 \%$; ${ }^{*}$ Significant at $10 \%$. 


\section{REFERENCES}

Adelman, C. 1999. Answers in the Tool Box: Academic Intensity, Attendance Patterns, and Bachelor's Degree Attainment. Washington, DC: U.S. Department of Education. (available at http://www.ed.gov/pubs/Toolbox/toolbox.html)

Agency for Healthcare Research and Quality (AHRQ). 2008. National Healthcare Disparities Report. United States Department of Health and Human Services, http://www.ahrq.gov/qual/nhdr08/nhdr08.pdf

Brown, S. V. 2000. "The Preparation of Minorities for Academic Careers in Science and Engineering: How Well are We Doing?" In G. Campbell Jr., R. Denes, and C. Morrison, (eds.) Access Denied: Race Ethnicity and the Scientific Enterprise. New York: Oxford University Press, pp. 239-269.

Commission to Build a Healthier America. 2009. Race and Socioeconomic Factors Affect Opportunities for Better Health. Robert Wood Johnson Foundation, http://www.commissiononhealth.org/PDF/506edea1-f160-4728-9539aba2357047e3/Issue\%20Brief\%205\%20April\%2009\%20\%20Race\%20and\%20Socioeconomic\%20Factors.pdf

Cox, T. H. 1993. Cultural Diversity in Organizations: Theory, Research, and Practice. San Francisco: Berrett-Keohler;

Gaughan, M. and Robin, S. 2004 . "National science training policy and early scientific careers in France and the United States." Research Policy, 33: 569-581.

Ginther, D. and K. Hayes. 2003. "Gender Differences in Salary and Promotion for Faculty in the Humanities." Journal of Human Resources 2003. 38:1, 34-73. 
Ginther, D. and S. Kahn. 2004. "Women in Economics: Moving Up or Falling Off the Academic Career Ladder." Journal of Economic Perspectives 18:3, 193-214.

Ginther, D. and S. Kahn. 2009. “Does Science Promote Women? Evidence from Academia 1973-2001," (2009) Science and Engineering Careers in the United States. Richard B. Freeman and Daniel F. Goroff (eds), Chicago, IL: University of Chicago Press for NBER Science Engineering Workforce Project.

Grandy, J. 1998. "Persistence in science of high-ability minority students: Results of a longitudinal study." The Journal of Higher Education. 69, 589-620.

Hosek, S.D., Cox, A. G., Ghosh-Dastidar, B. , Kofner, A., Ramphal, N., Scott, J., and Berry, S.H. 2005. Gender Differences in Major Federal External Grant Programs. Washington DC: Rand Report (TR-307-NSF).

Institute of Medicine (2001). Exploring the Biological Contributions to Human Health: Does Sex Matter? Washington, DC: National Academies Press.

Jackson, J. 2004. "The Story Is Not in the Numbers: Academic Socialization and Diversifying Faculty." NWSA Journal 16(1): 172-185.

Lee, C. 1991. Achieving Diversity: Issues in the recruitment and retention of underrepresented racial/ethnic students in higher education: A review of the literature. Alexandria, VA: National Association of College Admission Counselors.

Leggon, C.B. 2006. "Women in Science: Racial and Ethnic Differences and the Differences They Make." Journal of Technology Transfer 31: 325-333. 
Leggon, C.B. and S.M. Malcom. 1994. "Human Resources in Science and Engineering: Policy Implications." In W. Pearson Jr. and A. Fechter (eds.), Who Will Do Science? Educating the Next Generation. Baltimore, London: The Johns Hopkins University Press, pp. 141152.

Leggon, C.B. and Pearson, W. 1997. "The baccalaureate origins of African American female PhD scientists." Journal of Women and Minorities in Science and Engineering, 3: 213-224.

Lopatto, D. 2004. "Survey of Undergraduate Research Experiences (SURE): first finding". Cell Biol. Educ. 3, 270-277.

McLeod, P.L., Lobel, S.A., and T. H Cox. 1996. "Ethnic diversity and creativity in small groups." Small Group Research 27:248-265;

Myers, S.L. and C. S. Turner. 2004. "The effects of PhD supply on minority faculty representation." The American Economic Review. 94(2):296-301.

The National Academies. 2005. Assessment of NIH Minority Research and Training Programs: Phase 3, Washington, DC: National Academies Press.

The National Academies. 2007. Beyond Bias and Barriers: Fulfilling the Potential of Women in Academic Science and Engineering. Washington, DC: National Academies Press.

The National Institutes of Health. 2008. Research Supplments to Promote Diversity in HealthRelated Research. Available online at http://grants1.nih.gov/grants/guide/pa-files/PA08-190.html

National Research Council 2000. Addressing the Nation's Changing Needs for Biomedical and Behavioral Scientists. Washington, DC: National Academies Press. 
National Research Council 2005. Advancing the Nation's Health Needs: NIH Research Training Programs. Washington, DC: National Academies Press.

National Science Foundation, Division of Science Resources Statistics. 2007. "InfoBrief U.S. Doctoral Awards in Science and Engineering Continue Upward Trend in 2006." NSF 08301 (Arlington, VA; November 2007). Available from http://www.nsf.gov/statistics/infbrief/nsf08301/nsf08301.pdf

National Science Foundation, Division of Science Resources Statistics. 2009. "Women, Minorities, and Persons with Disabilities in Science and Engineering: 2009." NSF 09-305 (Arlington, VA; January 2009). Available from http://www.nsf.gov/statistics/wmpd/.

Nelson, D.J. 2007. "A national analysis of minorities in Science and Engineering Faculties at Research Universities." http://chem.ou.edu/ djn/diversity/Faculty_Tables_FY07/FinalReport07.html

Nettles, M.T. and Millett, C.M. 2006. Three Magic Letters: Getting to PhD. Baltimore, MD: Johns Hopkins Press.

Ntiri, D.W. 2001. "Access to higher education for nontraditional students and minorities in a technology-focused society." Urban Education. 36, 129-144.

Olson, S. and A.P. Fagen. 2007. Understanding Interventions that Encourage Minorities to Pursue Research Careers: Summary of a Workshop. Washington, DC: National Academies Press.

Opp, R.D. 2001. "Enhancing recruitment success for two-year college students of color." Community College Journal of Research and Practice. 25, 71-86. 
Sable, J., and Garofano, A. 2007. Public Elementary and Secondary School Student Enrollment, High School Completions, and Staff from the Common Core of Data: School Year 200506 (NCES 2007-352), National Center for Education Statistics, U.S. Department of Education, Washington, DC, http://nces.ed.gov/pubsearch/pubsinfo.asp?pubid=2007352.

Schiebinger, L. 2008. Gendered Innovations in Science and Engineering. Palo Alto, CA: Stanford University Press.

Seymour, E. and N.M. Hewitt. 1997. Talking About Leaving: Why undergraduates leave the sciences. Boulder, CO: Westview Press.

Sullivan Commission, 2004. Missing Persons: Minorities in the Health Professions. Available online at http://www.aacn.nche.edu/Media/pdf/SullivanReport.pdf.

Thomas D.A. 2004. “Diversity as strategy." Harvard Business Review 82(9):98-108.

Thomas, T.C. and Thurber, H.J. 1999. "Strategies for the recruitment and retention of Native American students: Executive Summary." (Educational Document Reproduction Service No: ED435514).

Turner, C.S.V., S.L Myers, and J.W. Creswell. 1999. “Exploring Underrepresentation: The Case of Faculty of Color in the Midwest." The Journal of Higher Education. 70(1): 27-59.

Villarejo, M., Barlow, A.E.L., Kogan, D., Veazey, B.D., and Sweeney, J.K. 2008. “Encouraging minority undergraduates to choose science careers: Career paths survey results." CBE Life Science Education 7(4): 394-409. 
Western Interstate Commission for Higher Education (2008). Knocking at the College Door: Projections of High School Graduates by State and Race/Ethnicity 1992-2022. Western Interstate Commission for Higher Education, Boulder CO. Accessed at http://www.wiche.edu/policy/knocking/1992-2022/knocking complete book.pdf on June 30, 2008.

Xie, Y. and Shauman, K.A. 2003. Women in Science: Career Processes and Outcomes. Cambridge, MA: Harvard University Press, Chapter 2. 
Table 1: Educational and Career Milestones of Life Scientists

\begin{tabular}{|c|c|c|c|c|}
\hline Milestone & Description & Year Range & Assumptions & Data Sources \\
\hline $\begin{array}{c}\text { General } \\
\text { Population }\end{array}$ & $\begin{array}{l}\text { Racial, ethnic and gender } \\
\text { characteristics for the } \\
\text { general U.S. population. }\end{array}$ & & & $\begin{array}{l}\text { U.S. Census Bureau, National } \\
\text { Population by age, gender, race } \\
\text { and Hispanic origin. }\end{array}$ \\
\hline High School & $\begin{array}{l}\text { The numbers of U.S. high } \\
\text { school graduates, by race, } \\
\text { ethnicity and gender. }\end{array}$ & $1979-1988$ & $\begin{array}{l}4 \text { to } 5 \text { years to } \\
\text { finish } \\
\text { undergraduate } \\
\text { studies }\end{array}$ & $\begin{array}{l}\text { U.S. Department of Education, } \\
\text { Institute of Education Sciences, } \\
\text { National Center for Education } \\
\text { Statistics, Common Core of Data }\end{array}$ \\
\hline College & $\begin{array}{l}\text { The numbers of U.S. 4- } \\
\text { year college/university } \\
\text { graduates, total } \\
\text { Bachelor's degrees, and } \\
\text { total with Bachelor's } \\
\text { degrees in life sciences }{ }^{1} \\
\text { and medicine, by race, } \\
\text { ethnicity and gender. }\end{array}$ & 1983-1992 & $\begin{array}{l}4 \text { to } 6 \text { years to } \\
\text { finish graduate } \\
\text { studies }\end{array}$ & $\begin{array}{l}\text { U.S. Department of Education, } \\
\text { Institute of Education Sciences, } \\
\text { National Center for Education } \\
\text { Statistics, Digest of Education } \\
\text { Statistics: 2006; National } \\
\text { Science Foundation, Science and } \\
\text { Engineering Indicators } 2008^{2} \text {. }\end{array}$ \\
\hline $\begin{array}{l}\text { Graduate and } \\
\text { Professional } \\
\text { Schools }\end{array}$ & $\begin{array}{l}\text { The numbers of U.S. PhD, } \\
\text { MDs and MD/PhD } \\
\text { recipients, total and with } \\
\text { degrees in life sciences } \\
\text { and medicine, by race, } \\
\text { ethnicity and gender. }\end{array}$ & $1988-1996$ & $\begin{array}{l}4 \text { to } 6 \text { years to } \\
\text { finish } \\
\text { postdoctoral } \\
\text { fellowship }\end{array}$ & $\begin{array}{c}\text { NSF Survey of Earned } \\
\text { Doctorates (SED); NSF Science } \\
\text { and Engineering Indicators } \\
\text { 2008; } 2008 \text { AAMC Data Book, } \\
\text { Association of American } \\
\text { Medical Schools }\end{array}$ \\
\hline $\begin{array}{l}\text { Faculty } \\
\text { Position }\end{array}$ & $\begin{array}{l}\text { The numbers of U.S. } \\
\text { assistant professors, total } \\
\text { and in life sciences and } \\
\text { medicine, by race, } \\
\text { ethnicity and gender. }\end{array}$ & $2000-2004$ & $\begin{array}{c}2 \text { to } 4 \text { years to } \\
\text { get R01 }\end{array}$ & $\begin{array}{l}\text { NSF SDR; NSF Science and } \\
\text { Engineering Indicators 2008; } \\
\text { American Association of } \\
\text { Medical Colleges Faculty Roster }\end{array}$ \\
\hline $\begin{array}{l}\text { First R01 } \\
\text { funded }\end{array}$ & $\begin{array}{l}\text { The numbers of NIH R01 } \\
\text { new investigators, by } \\
\text { race, ethnicity and } \\
\text { gender. }\end{array}$ & 2004-2006 & & NIH IMPACII \\
\hline
\end{tabular}

${ }^{1}$ Life Sciences as defined by the National Science Foundation include Agricultural Sciences, Biological Sciences and Medical/Other Life Sciences.

${ }^{2}$ National Science Board. 2008. Science and Engineering Indicators 2008. Arlington, VA: National Science Foundation (volume 1, NSB 08-01; volume 2, NSB 08-01A). 
Table 2: Number and Percent Representation of Each of the Major Gender and Racial/Ethnic Groups in the Graduate School Track

\begin{tabular}{|c|c|c|c|c|c|c|c|c|c|c|c|c|c|c|c|c|}
\hline & & \multicolumn{2}{|c|}{ Cohort 1} & \multicolumn{2}{|c|}{ Cohort 2} & \multicolumn{2}{|c|}{ Cohort 3} & \multicolumn{2}{|c|}{ Cohort 4} & \multicolumn{2}{|c|}{ Cohort 5} & \multicolumn{2}{|c|}{ Cohort 6} & \multicolumn{2}{|c|}{ Cohort 7} \\
\hline & & & Number & $\%$ & Number & $\%$ & Number & $\%$ & Number & $\%$ & Number & $\%$ & Number & $\%$ & Number & $\%$ \\
\hline & & & 1981 & & 1986 & & 198 & & 1990 & & 1992 & & 199 & & 199 & \\
\hline \multirow{10}{*}{\multicolumn{2}{|c|}{ 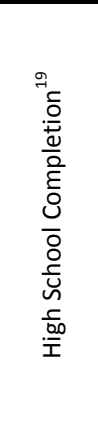 }} & White & & & & & & & & & $1,482,771$ & $65 \%$ & $1,485,861$ & $65 \%$ & $1,511,051$ & $65 \%$ \\
\hline & & Black & & & & & & & & & 247,858 & $11 \%$ & 276,274 & $12 \%$ & 266,704 & $11 \%$ \\
\hline & & Hispanic & & & & & & & & & 185,573 & $8 \%$ & 197,724 & $9 \%$ & 208,323 & $9 \%$ \\
\hline & & Asian & & & & & & & & & 90,816 & $4 \%$ & 94,602 & $4 \%$ & 90,395 & $4 \%$ \\
\hline & & & & & & & & & & & 17,739 & $1 \%$ & 18,077 & $1 \%$ & 20,125 & $1 \%$ \\
\hline & & Unknown & & & & & & & & & 255,115 & $11 \%$ & 212,882 & $9 \%$ & 235,281 & $10 \%$ \\
\hline & & Total & & & & & & & & & $2,279,872$ & $100 \%$ & $2,285,420$ & $100 \%$ & $2,331,879$ & $100 \%$ \\
\hline & & Male & $1,490,987$ & $49 \%$ & $1,331,927$ & $48 \%$ & $1,333,665$ & $50 \%$ & $1,172,879$ & $50 \%$ & $1,216,314$ & $51 \%$ & $1,244,155$ & $49 \%$ & $1,297,093$ & $49 \%$ \\
\hline & & Female & $1,564,920$ & $51 \%$ & $1,453,824$ & $52 \%$ & $1,339,467$ & $50 \%$ & $1,188,799$ & $50 \%$ & $1,180,313$ & $49 \%$ & $1,273,207$ & $51 \%$ & $1,362,516$ & $51 \%$ \\
\hline & & Total & $3,055,907$ & $100 \%$ & $2,785,751$ & $100 \%$ & $2,673,132$ & $100 \%$ & $2,361,678$ & $100 \%$ & $2,396,627$ & $100 \%$ & $2,517,362$ & $100 \%$ & $2,659,609$ & $100 \%$ \\
\hline \multirow{11}{*}{\multicolumn{2}{|c|}{ 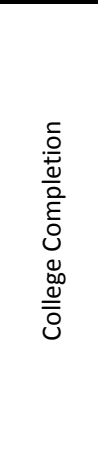 }} & & \multicolumn{2}{|l|}{1985} & \multicolumn{2}{|l|}{1990} & \multicolumn{2}{|c|}{1992} & \multicolumn{2}{|c|}{1994} & \multicolumn{2}{|c|}{1996} & \multicolumn{2}{|c|}{1998} & \multicolumn{2}{|c|}{2000} \\
\hline & & White & 31,818 & $83 \%$ & 28,814 & $78 \%$ & 32,506 & $76 \%$ & 37,942 & $74 \%$ & 43,739 & $72 \%$ & 45,912 & $70 \%$ & 43,907 & $69 \%$ \\
\hline & & Black & 2,047 & $5 \%$ & 1,994 & $5 \%$ & 2,385 & $6 \%$ & 2,980 & $6 \%$ & 3,812 & $6 \%$ & 4,553 & $7 \%$ & 4,739 & $7 \%$ \\
\hline & & Hispanic & 2,069 & $5 \%$ & 2,119 & $6 \%$ & 2,477 & $6 \%$ & 2,901 & $6 \%$ & 3,531 & $6 \%$ & 4,283 & $7 \%$ & 4,446 & $7 \%$ \\
\hline & & Asian & 1,952 & $5 \%$ & 3,245 & $9 \%$ & 4,402 & $10 \%$ & 5,959 & $12 \%$ & 7,967 & $13 \%$ & 8,869 & $14 \%$ & 8,025 & $13 \%$ \\
\hline & & Al & 161 & $0 \%$ & 130 & $0 \%$ & 181 & $0 \%$ & 246 & $0 \%$ & 317 & $1 \%$ & 399 & $1 \%$ & 379 & $1 \%$ \\
\hline & & Unknown & 443 & $1 \%$ & 871 & $2 \%$ & 891 & $2 \%$ & 1,030 & $2 \%$ & 1,348 & $2 \%$ & 1,673 & $3 \%$ & 2,032 & $3 \%$ \\
\hline & & Total & 38,490 & $100 \%$ & 37,173 & $100 \%$ & 42,842 & $100 \%$ & 51,058 & $100 \%$ & 60,714 & $100 \%$ & 65,689 & $100 \%$ & 63,528 & $100 \%$ \\
\hline & & Male & 19,931 & $52 \%$ & 18,200 & $49 \%$ & 20,628 & $48 \%$ & 24,739 & $48 \%$ & 28,603 & $47 \%$ & 29,331 & $45 \%$ & 26,399 & $42 \%$ \\
\hline & & Female & 18,559 & $48 \%$ & 18,973 & $51 \%$ & 22,214 & $52 \%$ & 26,319 & $52 \%$ & 32,111 & $53 \%$ & 36,358 & $55 \%$ & 37,129 & $58 \%$ \\
\hline & & Total & 38,490 & $100 \%$ & 37,179 & $100 \%$ & 42,842 & $100 \%$ & 51,058 & $100 \%$ & 60,714 & $100 \%$ & 65,689 & $100 \%$ & 63,528 & $100 \%$ \\
\hline \multirow{11}{*}{\multicolumn{2}{|c|}{ 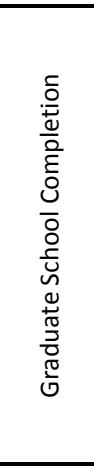 }} & & 1990 & & 1995 & & 199 & & 1999 & & 2001 & & 200 & & 200 & \\
\hline & & White & 2,976 & $88 \%$ & 3,115 & $72 \%$ & 3,157 & $74 \%$ & 3,128 & $76 \%$ & 3,258 & $77 \%$ & 3,059 & $75 \%$ & 3,337 & $76 \%$ \\
\hline & & Black & 51 & $2 \%$ & 107 & $2 \%$ & 112 & $3 \%$ & 116 & $3 \%$ & 139 & $3 \%$ & 108 & $3 \%$ & 158 & $4 \%$ \\
\hline & & Hispanic & 89 & $3 \%$ & 127 & $3 \%$ & 147 & $3 \%$ & 174 & $4 \%$ & 165 & $4 \%$ & 176 & $4 \%$ & 227 & $5 \%$ \\
\hline & & Asian & 200 & $6 \%$ & 920 & $21 \%$ & 721 & $17 \%$ & 608 & $15 \%$ & 559 & $13 \%$ & 548 & $14 \%$ & 551 & $13 \%$ \\
\hline & & Al & $*$ & $0 \%$ & 15 & $0 \%$ & 7 & $0 \%$ & 20 & $0 \%$ & 15 & $0 \%$ & 11 & $0 \%$ & 12 & $0 \%$ \\
\hline & & Unknown & $*$ & $2 \%$ & 45 & $1 \%$ & 112 & $3 \%$ & 77 & $2 \%$ & 112 & $3 \%$ & 157 & $4 \%$ & 111 & $3 \%$ \\
\hline & & Total & 3,381 & $100 \%$ & 4,329 & $100 \%$ & 4,256 & $100 \%$ & 4,123 & $100 \%$ & 4,248 & $100 \%$ & 4,059 & $100 \%$ & 4,396 & $100 \%$ \\
\hline & & Male & 2,068 & $61 \%$ & 2,469 & $57 \%$ & 2,333 & $55 \%$ & 2,259 & $55 \%$ & 2,275 & $54 \%$ & 2,141 & $53 \%$ & 2,227 & $51 \%$ \\
\hline & & Female & 1,313 & $39 \%$ & 1,859 & $43 \%$ & 1,920 & $45 \%$ & 1,864 & $45 \%$ & 1,973 & $46 \%$ & 1,918 & $47 \%$ & 2,168 & $49 \%$ \\
\hline & & Total & 3,381 & $100 \%$ & 4,329 & $100 \%$ & 4,256 & $100 \%$ & 4,123 & $100 \%$ & 4,248 & $100 \%$ & 4,059 & $100 \%$ & 4,395 & $100 \%$ \\
\hline & & & 1995 & & 2000 & & 200 & & 2004 & & 2006 & & & & & \\
\hline & & White & & & 25,502 & $71 \%$ & 28,707 & $72 \%$ & 29,750 & $65 \%$ & 31,477 & $63 \%$ & & & & \\
\hline & & Black & & & 1,338 & $4 \%$ & 1,581 & $4 \%$ & 1,926 & $4 \%$ & 2,081 & $4 \%$ & & & & \\
\hline ¿̀ & 음 & Hispanic & & & 1,366 & $4 \%$ & 1,897 & $5 \%$ & 2,257 & $5 \%$ & 2,593 & $5 \%$ & & & & \\
\hline 屯ัँ & $\frac{\bar{U}}{\pi}$ & Asian & & & 4,758 & $13 \%$ & 5,873 & $15 \%$ & 7,282 & $16 \%$ & 8,317 & $17 \%$ & & & & \\
\hline 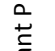 & $\frac{\tilde{U}}{0}$ & Al & & & 63 & $0 \%$ & 51 & $0 \%$ & 48 & $0 \%$ & 68 & $0 \%$ & & & & \\
\hline$\stackrel{\mathbb{N}}{. \underline{n}}$ & $\sum^{\infty}$ & Unknown & & & 2,864 & $8 \%$ & 1,913 & $5 \%$ & 4,435 & $10 \%$ & 5,687 & $11 \%$ & & & & \\
\hline 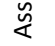 & ஸ் & Total & & & 35,891 & $100 \%$ & 40,022 & $100 \%$ & 45,698 & $100 \%$ & 50,223 & $100 \%$ & & & & \\
\hline & & Male & & & 23,272 & $65 \%$ & 25,667 & $64 \%$ & 28,613 & $63 \%$ & 30,708 & $61 \%$ & & & & \\
\hline & & Female & & & 12,619 & $35 \%$ & 14,355 & $36 \%$ & 17,085 & $37 \%$ & 19,515 & $39 \%$ & & & & \\
\hline & & Total & & & 35,891 & $100 \%$ & 40,022 & $100 \%$ & 45,698 & $100 \%$ & 50,223 & $100 \%$ & & & & \\
\hline
\end{tabular}

${ }^{19}$ Totals for high school completers differ because the data come from surveys with different methodologies. Race/ethnicity data come from a survey that counts high school completions from public schools. Gender data only available from a study that estimates high school completions from a sample and includes all 16 to 24 year olds who received a high school diploma or GED.

*data suppressed to prevent disclosure. 
Table 3: Transition Ratios by Gender and Race/Ethnicity for the Indicated Transition for Each Cohort.

\begin{tabular}{|c|c|c|c|c|c|c|c|c|}
\hline & & \multirow{2}{*}{$\begin{array}{c}\text { Cohort } 1 \\
1985\end{array}$} & \multirow{2}{*}{$\begin{array}{c}\text { Cohort } 2 \\
1990\end{array}$} & \multirow{2}{*}{$\begin{array}{c}\text { Cohort } 3 \\
1992\end{array}$} & \multirow{2}{*}{$\begin{array}{c}\text { Cohort } 4 \\
1994\end{array}$} & \multirow{2}{*}{$\frac{\text { Cohort } 5}{1996}$} & \multirow{2}{*}{$\begin{array}{c}\text { Cohort } 6 \\
1998\end{array}$} & \multirow{2}{*}{$\begin{array}{r}\text { Cohort } 7 \\
2000\end{array}$} \\
\hline & & & & & & & & \\
\hline \multirow{8}{*}{ 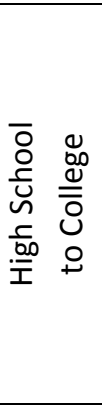 } & White & & & & & 1.108 & 1.075 & 1.067 \\
\hline & Black & & & & & 0.578 & 0.573 & 0.652 \\
\hline & Hispanic & & & & & 0.715 & 0.754 & 0.783 \\
\hline & Asian & & & & & 3.294 & 3.262 & 3.259 \\
\hline & $\mathrm{Al}$ & & & & & 0.671 & 0.768 & 0.691 \\
\hline & Unknown & & & & & 0.198 & 0.273 & 0.317 \\
\hline & Male & 1.061 & 1.024 & 0.965 & 0.976 & 0.928 & 0.903 & 0.852 \\
\hline & Female & 0.942 & 0.978 & 1.035 & 1.024 & 1.074 & 1.094 & 1.141 \\
\hline & & 1990 & 1995 & 1997 & 1999 & 2001 & 2003 & 2005 \\
\hline \multirow{9}{*}{ 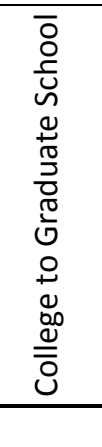 } & White & 1.065 & 0.928 & 0.978 & 1.021 & 1.065 & 1.078 & 1.098 \\
\hline & Black & 0.284 & 0.461 & 0.473 & 0.482 & 0.521 & 0.384 & 0.482 \\
\hline & Hispanic & 0.490 & 0.515 & 0.597 & 0.743 & 0.668 & 0.665 & 0.738 \\
\hline & Asian & 1.166 & 2.435 & 1.649 & 1.264 & 1.003 & 1.000 & 0.992 \\
\hline & $\mathrm{Al}$ & 0.283 & 0.991 & 0.389 & 1.007 & 0.676 & 0.446 & 0.458 \\
\hline & Unknown & 1.568 & 0.444 & 1.265 & 0.926 & 1.187 & 1.519 & 0.789 \\
\hline & Male & 1.181 & 1.165 & 1.138 & 1.131 & 1.137 & 1.181 & 1.219 \\
\hline & Female & 0.805 & 0.841 & 0.870 & 0.877 & 0.878 & 0.854 & 0.844 \\
\hline & & 1995 & 2000 & 2002 & 2004 & 2006 & & \\
\hline \multirow{8}{*}{ 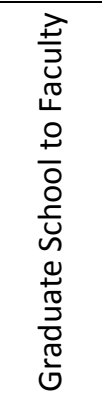 } & White & & 0.987 & 0.967 & 0.858 & 0.817 & & \\
\hline & Black & & 1.508 & 1.501 & 1.498 & 1.266 & & \\
\hline & Hispanic & & 1.297 & 1.372 & 1.170 & 1.329 & & \\
\hline & Asian & & 0.624 & 0.866 & 1.081 & 1.258 & & \\
\hline & $\mathrm{Al}$ & & 0.507 & 0.775 & 0.217 & 0.383 & & \\
\hline & Unknown & & 7.676 & 1.816 & 5.197 & 4.295 & & \\
\hline & Male & & 1.137 & 1.170 & 1.143 & 1.142 & & \\
\hline & Female & & 0.819 & 0.795 & 0.827 & 0.837 & & \\
\hline
\end{tabular}


Table 4: Number and Percent Representation by Gender and Race/Ethnicity for the Medical School Track

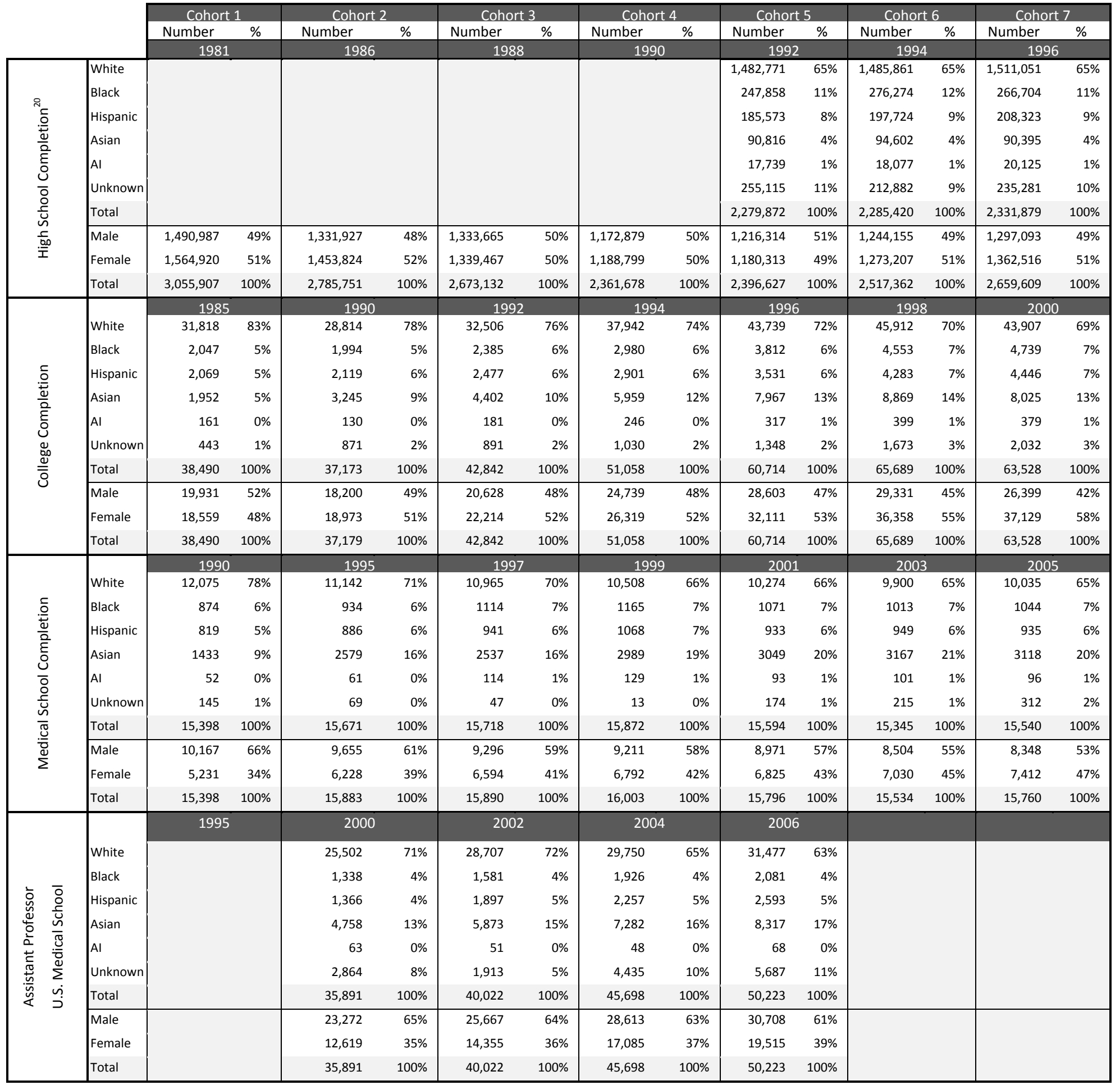

${ }^{20}$ Totals for high school completers differ because the data come from surveys with different methodologies. Race/ethnicity data come from a survey that counts high school completions from public schools. Gender data is only available from a study that estimates high school completions from a sample and includes all 16 to 24 year olds who received a high school diploma or GED. 
Table 5: Transition Ratios by Gender and Race/Ethnicity for Each Cohort on the Medical Degree Track.

\begin{tabular}{|c|c|c|c|c|c|c|c|c|}
\hline & Cohort 1 & Cohort 2 & Cohort 3 & Cohort 4 & Cohort 5 & Cohort 6 & Cohort 7 \\
\hline & & 1985 & 1990 & 1992 & 1994 & 1996 & 1998 & 2000 \\
\hline \multirow{9}{*}{ 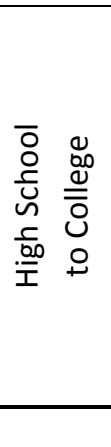 } & White & & & & & 1.108 & 1.075 & 1.067 \\
\hline & Black & & & & & 0.578 & 0.573 & 0.652 \\
\hline & Hispanic & & & & & 0.715 & 0.754 & 0.783 \\
\hline & Asian & & & & & 3.294 & 3.262 & 3.259 \\
\hline & $\mathrm{Al}$ & & & & & 0.671 & 0.768 & 0.691 \\
\hline & Unknown & & & & & 0.198 & 0.273 & 0.317 \\
\hline & Male & 1.061 & 1.024 & 0.965 & 0.976 & 0.928 & 0.903 & 0.852 \\
\hline & Female & 0.942 & 0.978 & 1.035 & 1.024 & 1.074 & 1.094 & 1.141 \\
\hline & & 1990 & 1995 & 1997 & 1999 & 2001 & 2003 & 2005 \\
\hline \multirow{9}{*}{ 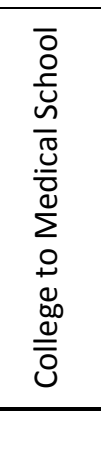 } & White & 0.949 & 0.917 & 0.919 & 0.891 & 0.915 & 0.923 & 0.934 \\
\hline & Black & 1.067 & 1.111 & 1.273 & 1.258 & 1.094 & 0.952 & 0.901 \\
\hline & Hispanic & 0.989 & 0.992 & 1.035 & 1.184 & 1.029 & 0.949 & 0.860 \\
\hline & Asian & 1.835 & 1.885 & 1.571 & 1.614 & 1.490 & 1.529 & 1.588 \\
\hline & $\mathrm{Al}$ & 0.807 & 1.113 & 1.717 & 1.687 & 1.142 & 1.084 & 1.035 \\
\hline & Unknown & 0.818 & 0.188 & 0.144 & 0.041 & 0.503 & 0.550 & 0.628 \\
\hline & Male & 1.275 & 1.242 & 1.215 & 1.188 & 1.206 & 1.226 & 1.275 \\
\hline & Female & 0.705 & 0.768 & 0.800 & 0.823 & 0.817 & 0.818 & 0.805 \\
\hline & & 1995 & 2000 & 2002 & 2004 & 2006 & & \\
\hline \multirow{8}{*}{ 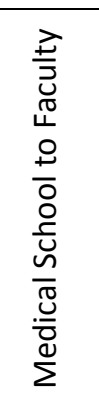 } & White & & 0.999 & 1.028 & 0.983 & 0.951 & & \\
\hline & Black & & 0.625 & 0.557 & 0.574 & 0.603 & & \\
\hline & Hispanic & & 0.673 & 0.792 & 0.734 & 0.863 & & \\
\hline & Asian & & 0.806 & 0.909 & 0.846 & 0.847 & & \\
\hline & & & 0.451 & 0.176 & 0.129 & 0.227 & & \\
\hline & Unknown & & 18.123 & 15.985 & 118.491 & 10.148 & & \\
\hline & Male & & 1.067 & 1.096 & 1.088 & 1.077 & & \\
\hline & Female & & 0.897 & 0.864 & 0.881 & 0.899 & & \\
\hline
\end{tabular}


Table 6: Demographic Differences in the Probability of Receiving a Tenure Track Job within 7 Years of Doctorate, 1985 - 2006 Survey of Doctorate Recipients

\begin{tabular}{|c|c|c|c|c|c|}
\hline Model & 1 & 2 & 3 & 4 & 5 \\
\hline \multirow[t]{2}{*}{ Female } & $0.033^{*}$ & 0.008 & 0.006 & 0.024 & 0.023 \\
\hline & {$[0.018]$} & [0.019] & [0.019] & {$[0.019]$} & [0.019] \\
\hline \multirow[t]{2}{*}{ Black } & $0.067^{*}$ & 0.044 & 0.043 & 0.058 & $0.092 * *$ \\
\hline & {$[0.040]$} & [0.039] & [0.039] & [0.040] & [0.045] \\
\hline \multirow[t]{2}{*}{ Asian } & $-0.069 * *$ & $-0.068 * *$ & $-0.072 * *$ & $-0.068 * *$ & $-0.082 *$ \\
\hline & {$[0.032]$} & {$[0.032]$} & [0.032] & [0.032] & [0.044] \\
\hline \multirow[t]{2}{*}{ Native American } & -0.105 & $-0.126 *$ & $-0.126 *$ & -0.108 & -0.108 \\
\hline & {$[0.061]$} & {$[0.058]$} & [0.057] & {$[0.062]$} & {$[0.062]$} \\
\hline \multirow[t]{2}{*}{ Hispanic } & $0.115^{* * *}$ & $0.124^{* * *}$ & $0.124 * * *$ & $0.126^{* * *}$ & $0.101^{* *}$ \\
\hline & {$[0.043]$} & [0.043] & {$[0.043]$} & {$[0.043]$} & [0.047] \\
\hline \multirow[t]{2}{*}{ Foreign Born } & $-0.055^{*}$ & $-0.059 * *$ & $-0.055^{*}$ & $-0.065^{* *}$ & -0.065 \\
\hline & [0.029] & [0.029] & [0.029] & [0.029] & [0.040] \\
\hline \multirow[t]{2}{*}{ Foreign Born*Black } & & & & & $-0.161 *$ \\
\hline & & & & & {$[0.070]$} \\
\hline \multirow[t]{2}{*}{ Foreign Born*Asian } & & & & & 0.023 \\
\hline & & & & & {$[0.076]$} \\
\hline \multirow[t]{2}{*}{ Foreign Born*Hispanic } & & & & & 0.147 \\
\hline & & & & & {$[0.122]$} \\
\hline \multicolumn{6}{|l|}{ Additional Controls: } \\
\hline Age at $\mathrm{PhD}$ and $\mathrm{PhD}$ Year & Yes & Yes & Yes & Yes & Yes \\
\hline PhD Field & No & Yes & Yes & Yes & Yes \\
\hline PhD Characteristics & No & No & Yes & Yes & Yes \\
\hline Marital Status and Children & No & No & No & Yes & Yes \\
\hline Sample Size & 2704 & 2704 & 2704 & 2704 & 2704 \\
\hline
\end{tabular}

Notes: Probit model includes controls for gender, race/ethnicity, foreign born, PhD Field, Carnegie Ranking of PhD Institution, Marital Status, and number of children. Coefficients report marginal effects. Robust Standard errors in brackets. ${ }^{* * *}$ Significant at $1 \%$; ${ }^{* *}$ Significant at $5 \%$; ${ }^{*}$ Significant at $10 \%$. 
Table 7: Demographic Differences in the Probability of Receiving Tenure within 10 Years of Doctorate, 1985 - 2006 Survey of Doctorate Recipients

\begin{tabular}{|c|c|c|c|c|c|}
\hline Model & 1 & 2 & 3 & 4 & 5 \\
\hline \multirow[t]{2}{*}{ Female } & $-0.092 * *$ & $-0.074 * *$ & -0.063 & -0.063 & -0.066 \\
\hline & [0.036] & [0.037] & [0.039] & [0.051] & {$[0.051]$} \\
\hline \multirow[t]{2}{*}{ Black } & 0.07 & 0.071 & 0.055 & 0.150 & $0.223 * *$ \\
\hline & {$[0.073]$} & [0.073] & {$[0.075]$} & [0.095] & {$[0.100]$} \\
\hline \multirow[t]{2}{*}{ Asian } & -0.042 & -0.030 & 0.005 & 0.067 & 0.005 \\
\hline & {$[0.069]$} & {$[0.070]$} & {$[0.075]$} & [0.093] & {$[0.128]$} \\
\hline \multirow[t]{2}{*}{ Native American } & -0.130 & -0.131 & $-0.201 *$ & -0.215 & -0.218 \\
\hline & {$[0.102]$} & [0.103] & {$[0.086]$} & [0.140] & [0.140] \\
\hline \multirow[t]{2}{*}{ Hispanic } & 0.042 & 0.034 & 0.002 & 0.112 & 0.113 \\
\hline & {$[0.067]$} & [0.066] & [0.069] & [0.092] & [0.102] \\
\hline \multirow[t]{2}{*}{ Foreign Born } & $-0.117^{* *}$ & $-0.129 * *$ & $-0.127 * *$ & $-0.216 * * *$ & $-0.194 *$ \\
\hline & {$[0.055]$} & {$[0.054]$} & {$[0.055]$} & {$[0.073]$} & {$[0.106]$} \\
\hline \multirow[t]{2}{*}{ Foreign Born*Black } & & & & & -0.325 \\
\hline & & & & & [0.167] \\
\hline \multirow[t]{2}{*}{ Foreign Born*Asian } & & & & & 0.08 \\
\hline & & & & & [0.192] \\
\hline \multirow[t]{2}{*}{ Foreign Born*Hispanic } & & & & & -0.016 \\
\hline & & & & & {$[0.246]$} \\
\hline \multicolumn{6}{|l|}{ Additional Time-Invariant Controls: } \\
\hline Age and Year at PhD & Yes & Yes & Yes & Yes & Yes \\
\hline PhD Field & Yes & Yes & Yes & Yes & Yes \\
\hline PhD Characteristics & Yes & Yes & Yes & Yes & Yes \\
\hline \multicolumn{6}{|l|}{ Additional Controls 10 Years Past PhD: } \\
\hline Marital Status and Children & No & Yes & Yes & Yes & Yes \\
\hline Employer Characteristics & No & No & Yes & Yes & Yes \\
\hline Cumulative Employers & No & No & Yes & Yes & Yes \\
\hline Cumulative Government Support, Publications & No & No & No & Yes & Yes \\
\hline Sample Size & 883 & 883 & 880 & 666 & 666 \\
\hline
\end{tabular}

Notes: Probit model includes controls for gender, race/ethnicity, foreign born, PhD Field, Carnegie Ranking of PhD Institution, and the following characteristics measured 10 Years past PhD: Marital Status, number of children, employer characteristics (public institution, Carnegie Ranking, Medical School), Government support; and Cumulative (number of employers, government support, paper presentations and publications). Coefficients report marginal effects. Robust Standard errors in brackets. ***Significant at $1 \%$; * Significant at $5 \%$; ${ }^{*}$ Significant at $10 \%$. 
Table 8: Demographic Differences in the Percent Tenured within 10 Years of PhD by University Type, 1985 - 2006 Survey of Doctorate Recipients

\begin{tabular}{|c|c|c|c|c|c|c|c|c|c|c|}
\hline \multirow{2}{*}{$\begin{array}{c}\text { University } \\
\text { Type }\end{array}$} & \multirow[b]{2}{*}{ Total } & \multicolumn{7}{|c|}{ Native } & \multirow{2}{*}{$\begin{array}{l}\text { Foreign } \\
\text { Born }\end{array}$} & \multirow{2}{*}{$\begin{array}{l}\text { Native } \\
\text { Born }\end{array}$} \\
\hline & & White & Black & Asian & American & Hispanic & $\underline{\text { Women }}$ & Men & & \\
\hline Liberal Arts & $33.8 \%$ & $29.2 \%$ & $45.8 \%$ & $33.3 \%$ & $80.0 \%$ & $60.0 \%$ & $37.5 \%$ & $31.0 \%$ & $25.8 \%$ & $34.7 \%$ \\
\hline University & $15.2 \%$ & $16.6 \%$ & $12.5 \%$ & $9.5 \%$ & $0.0 \%$ & $12.0 \%$ & $14.6 \%$ & $15.8 \%$ & $12.9 \%$ & $15.5 \%$ \\
\hline Research I & $34.8 \%$ & $36.0 \%$ & $33.3 \%$ & $42.9 \%$ & $20.0 \%$ & $20.0 \%$ & $31.3 \%$ & $37.5 \%$ & $48.4 \%$ & $33.3 \%$ \\
\hline Other & $16.2 \%$ & $18.2 \%$ & $8.3 \%$ & $14.3 \%$ & $0.0 \%$ & $8.0 \%$ & $16.7 \%$ & $15.8 \%$ & $12.9 \%$ & $16.5 \%$ \\
\hline Tenure Rate & $37.1 \%$ & $38.5 \%$ & $46.2 \%$ & $22.8 \%$ & $29.4 \%$ & $38.5 \%$ & $37.6 \%$ & $36.8 \%$ & $25.0 \%$ & $39.1 \%$ \\
\hline Total in Sample & 883 & 657 & 52 & 92 & 17 & 65 & 383 & 500 & 124 & 759 \\
\hline
\end{tabular}

Notes: Estimates based on individuals who had held tenure track jobs and were observed in sample within 10 years of $\mathrm{PhD}$ 
Table 9: Demographic Differences in the Probability of Receiving NIH Funding within 10 Years of Doctorate, 1985 - 2003 Survey of Doctorate Recipients

\begin{tabular}{|c|c|c|c|c|c|}
\hline Model & 1 & 2 & 3 & 4 & 5 \\
\hline \multirow[t]{2}{*}{ Female } & $0.061^{*}$ & 0.062 & 0.062 & $0.085^{* *}$ & $0.084 * *$ \\
\hline & [0.033] & [0.038] & {$[0.040]$} & {$[0.041]$} & [0.041] \\
\hline \multirow[t]{2}{*}{ Black } & $-0.126 * *$ & -0.083 & -0.023 & -0.010 & -0.011 \\
\hline & {$[0.058]$} & {$[0.072]$} & {$[0.078]$} & {$[0.080]$} & {$[0.086]$} \\
\hline \multirow[t]{2}{*}{ Asian } & -0.081 & -0.055 & -0.079 & -0.071 & -0.124 \\
\hline & {$[0.061]$} & {$[0.068]$} & {$[0.071]$} & {$[0.072]$} & [0.100] \\
\hline \multirow[t]{2}{*}{ Native American } & 0.022 & 0.113 & $0.220 *$ & $0.242^{*}$ & $0.243^{*}$ \\
\hline & {$[0.113]$} & [0.126] & {$[0.127]$} & [0.127] & [0.127] \\
\hline \multirow[t]{2}{*}{ Hispanic } & $-0.103^{*}$ & -0.059 & 0.026 & 0.035 & 0.063 \\
\hline & {$[0.059]$} & {$[0.067]$} & {$[0.073]$} & [0.074] & {$[0.082]$} \\
\hline \multirow[t]{2}{*}{ Foreign Born } & 0.037 & 0.027 & 0.004 & -0.009 & -0.012 \\
\hline & {$[0.056]$} & [0.062] & {$[0.066]$} & [0.066] & [0.095] \\
\hline \multirow[t]{2}{*}{ Foreign Born*Black } & & & & & 0.010 \\
\hline & & & & & {$[0.243]$} \\
\hline \multirow[t]{2}{*}{ Foreign Born*Asian } & & & & & 0.083 \\
\hline & & & & & [0.162] \\
\hline \multirow[t]{2}{*}{ Foreign Born*Hispanic } & & & & & -0.127 \\
\hline & & & & & {$[0.176]$} \\
\hline \multicolumn{6}{|l|}{ Additional Time-Invariant Controls: } \\
\hline Age and Year at PhD & Yes & Yes & Yes & Yes & Yes \\
\hline PhD Field & Yes & Yes & Yes & Yes & Yes \\
\hline PhD Characteristics & Yes & Yes & Yes & Yes & Yes \\
\hline \multicolumn{6}{|l|}{ Additional Controls 10 Years Past PhD: } \\
\hline Marital Status and Children & No & Yes & Yes & Yes & Yes \\
\hline Employer Characteristics & No & No & Yes & Yes & Yes \\
\hline Cumulative Employers & No & No & Yes & Yes & Yes \\
\hline Cumulative Government Support, Publications & No & No & No & Yes & Yes \\
\hline Sample Size & 1120 & 883 & 880 & 880 & 880 \\
\hline
\end{tabular}

Notes: Probit model includes controls for gender, race/ethnicity, foreign born, PhD Field, Carnegie Ranking of PhD Institution, and the following characteristics measured 10 years past PhD: Marital Status, number of children, employer characteristics (public institution, Carnegie Ranking, Medical School), Government support; and Cumulative (number of employers, government support, paper presentations and publications). Coefficients report marginal effects. Robust Standard errors in brackets. ***Significant at $1 \% ; * *$ Significant at $5 \%$; *Significant at $10 \%$. 
Table 10: Demographic Differences in the Probability of Receiving NSF Funding within 10 Years of Doctorate, 1985 - 2003 Survey of Doctorate Recipients

\begin{tabular}{|c|c|c|c|c|c|}
\hline Model & 1 & 2 & 3 & 4 & 5 \\
\hline \multirow[t]{2}{*}{ Female } & -0.001 & -0.001 & 0.002 & 0.008 & 0.010 \\
\hline & {$[0.018]$} & {$[0.020]$} & {$[0.018]$} & {$[0.018]$} & {$[0.018]$} \\
\hline \multirow[t]{2}{*}{ Black } & -0.002 & -0.003 & -0.025 & -0.023 & -0.033 \\
\hline & {$[0.039]$} & {$[0.046]$} & {$[0.032]$} & {$[0.032]$} & [0.029] \\
\hline \multirow[t]{2}{*}{ Asian } & -0.023 & -0.028 & -0.023 & -0.022 & 0.037 \\
\hline & {$[0.029]$} & {$[0.031]$} & {$[0.027]$} & {$[0.027]$} & {$[0.052]$} \\
\hline \multirow[t]{2}{*}{ Native American } & $0.187 * *$ & $0.214^{* *}$ & $0.159 *$ & $0.169 *$ & $0.172^{*}$ \\
\hline & {$[0.115]$} & [0.138] & [0.123] & [0.125] & [0.126] \\
\hline \multirow[t]{2}{*}{ Hispanic } & -0.007 & -0.003 & -0.023 & -0.022 & -0.024 \\
\hline & {$[0.031]$} & [0.034] & {$[0.025]$} & {$[0.025]$} & {$[0.026]$} \\
\hline \multirow[t]{2}{*}{ Foreign Born } & -0.036 & -0.035 & -0.031 & -0.034 & -0.008 \\
\hline & {$[0.025]$} & [0.027] & {$[0.023]$} & {$[0.022]$} & {$[0.037]$} \\
\hline \multirow[t]{2}{*}{ Foreign Born*Black } & & & & & 0.161 \\
\hline & & & & & {$[0.261]$} \\
\hline \multirow[t]{2}{*}{ Foreign Born*Asian } & & & & & $-0.073 * *$ \\
\hline & & & & & {$[0.020]$} \\
\hline \multirow[t]{2}{*}{ Foreign Born*Hispanic } & & & & & -0.002 \\
\hline & & & & & {$[0.076]$} \\
\hline \multicolumn{6}{|l|}{ Additional Time-Invariant Controls: } \\
\hline Age and Year at PhD & Yes & Yes & Yes & Yes & Yes \\
\hline PhD Field & Yes & Yes & Yes & Yes & Yes \\
\hline PhD Characteristics & Yes & Yes & Yes & Yes & Yes \\
\hline \multicolumn{6}{|l|}{ Additional Controls 10 Years Past PhD: } \\
\hline Marital Status and Children & No & Yes & Yes & Yes & Yes \\
\hline Employer Characteristics & No & No & Yes & Yes & Yes \\
\hline Cumulative Employers & No & No & Yes & Yes & Yes \\
\hline Cumulative Government Support, Publications & No & No & No & Yes & Yes \\
\hline Sample Size & 1120 & 883 & 880 & 880 & 880 \\
\hline
\end{tabular}

Notes: Probit model includes controls for gender, race/ethnicity, foreign born, PhD Field, Carnegie Ranking of PhD Institution, and the following characteristics measured 10 years past PhD: Marital Status, number of children, employer characteristics (public institution, Carnegie Ranking, Medical School), Government support; and Cumulative (number of employers, government support, paper presentations and publications). Coefficients report marginal effects. Robust Standard errors in brackets. ${ }^{* * *}$ Significant at $1 \% ; * *$ Significant at $5 \%$; $*$ Significant at $10 \%$. 
Figure 1: Career Progression Model for Biomedical Scientists Used In Study

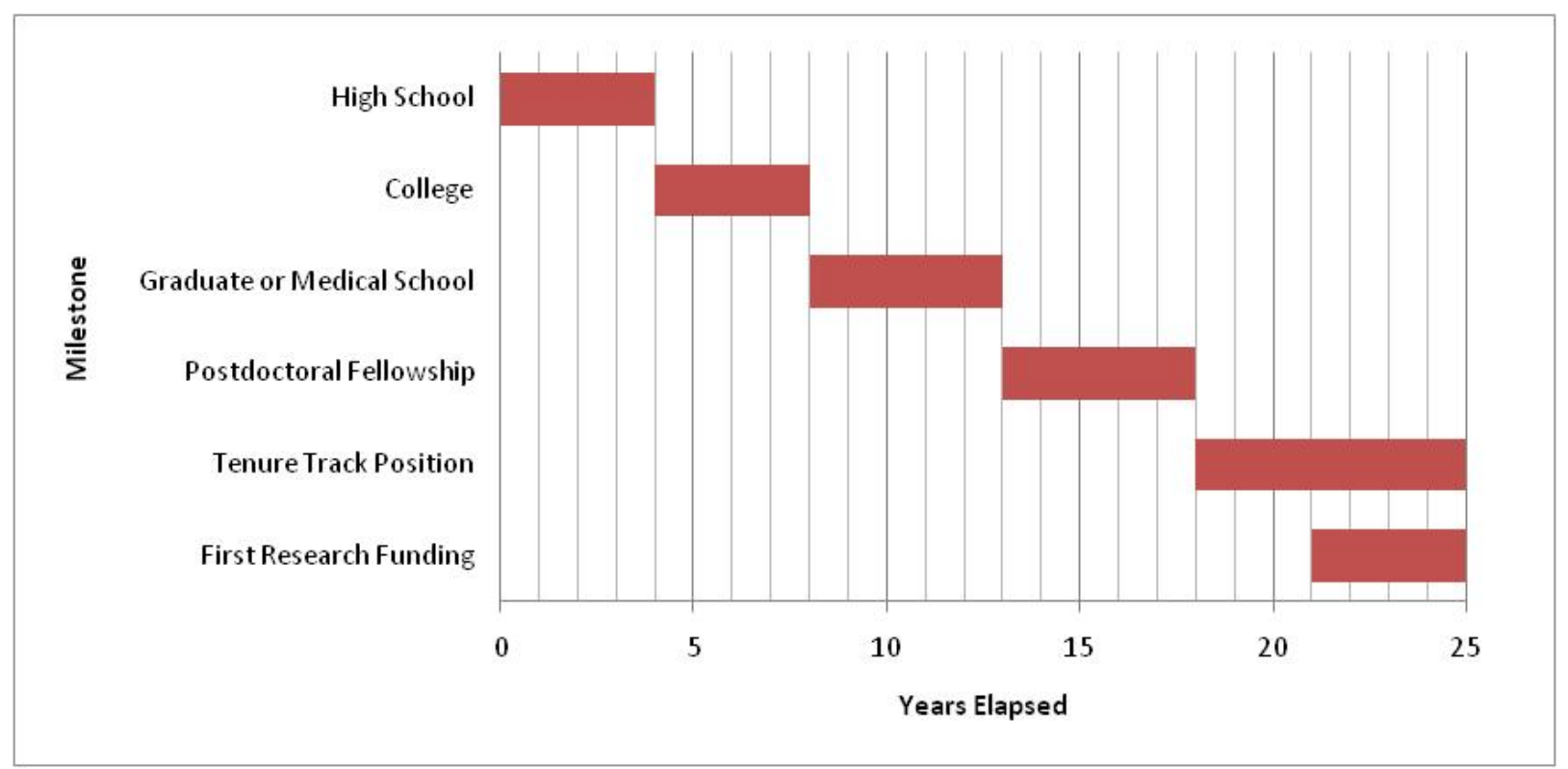

